مفهوم النفس عند الكندي و الفارابي و ابن سينا و الغزالي

إعداد

د. سميرة حسن حامد محمد

كلية الآداب والعلوم الإنسانية

قسم الشريعة والدراسات الإسلامية

جامعة الملك عبد العزيز

المملكة العربية السعودية

الملخص:

مفهوم النفس عند الكندي والفارابي وابن سينا والغزالي.

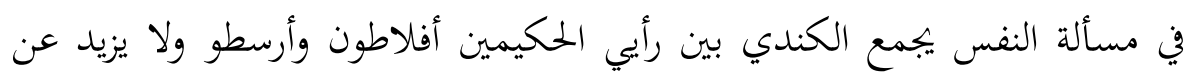

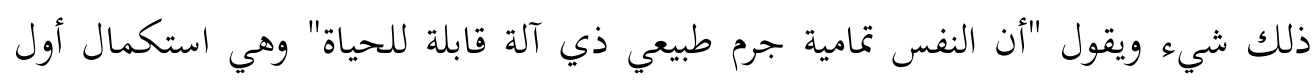

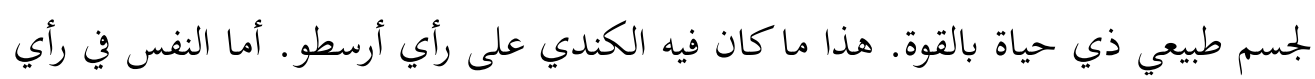

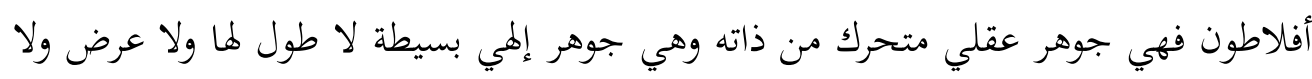

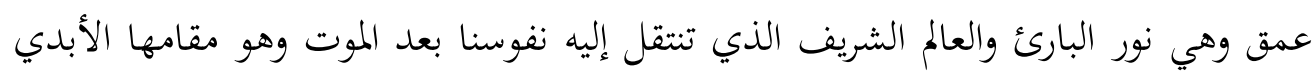

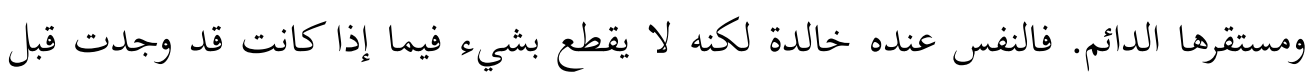

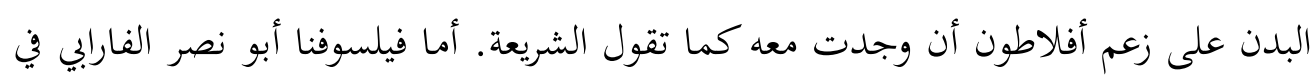

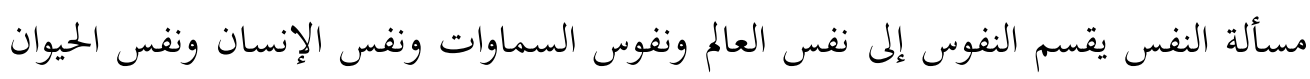

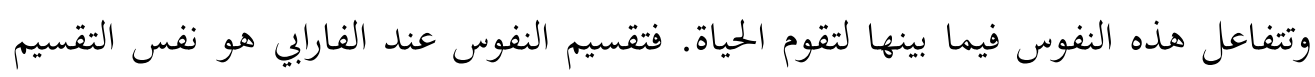
الذي نجده عند أرسطو في كتاب النفس.

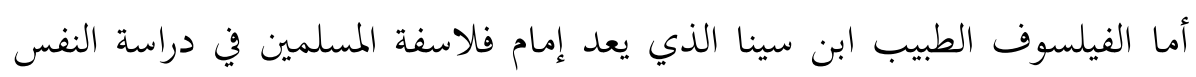

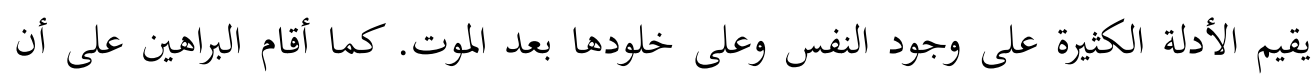

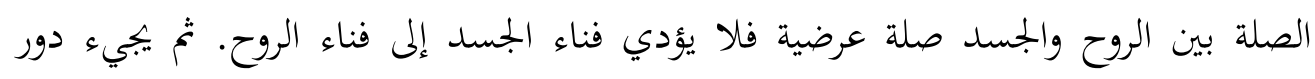

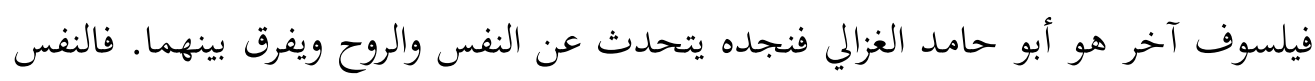


لديه هي ذلك الجوهر الذي يجمع بين العالمين وهما عالم العقل أي العالم الإلهي وعالم الحس أي ألماي

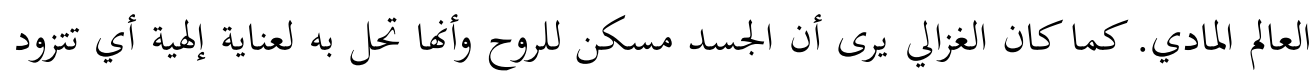

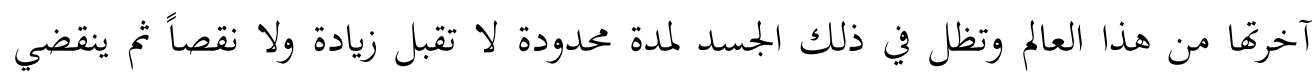
أجلها.

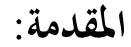

إن الحمد لله نخمده ونستعينه ونستغفره ونستهديه ونعوذ بالله من شرور أنفسنا ومن

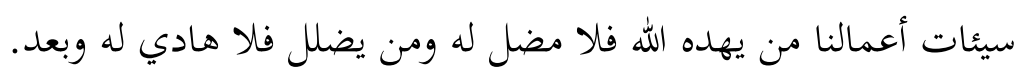

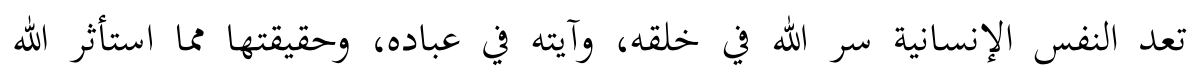

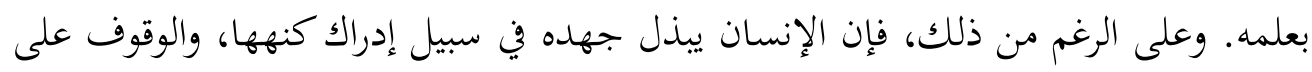

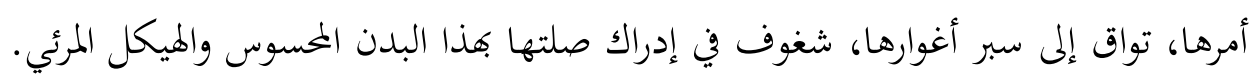

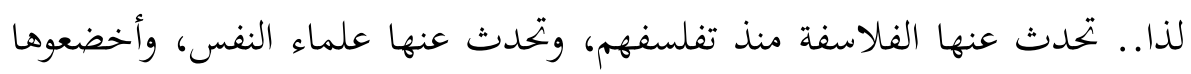

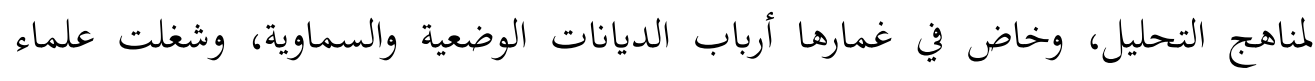

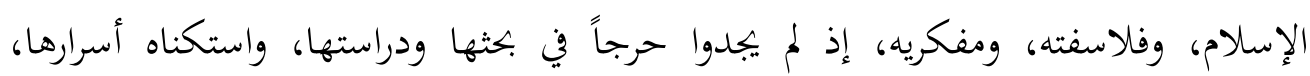

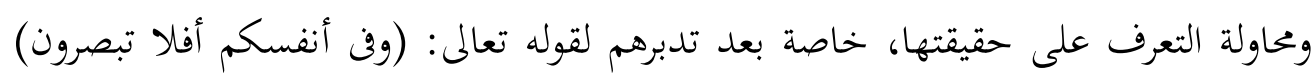

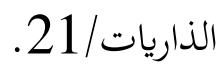

كما تحتل مسألة "النفس" مكاناً بارزاً على صعيد الفكر الإنساني عامة، والفكر

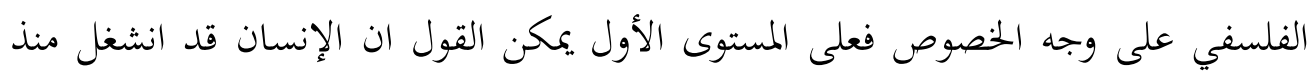

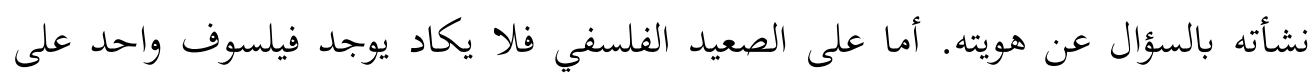

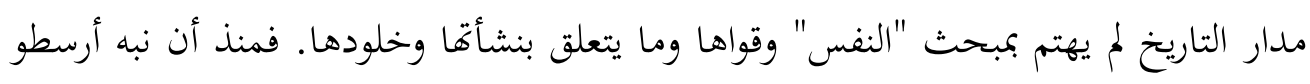

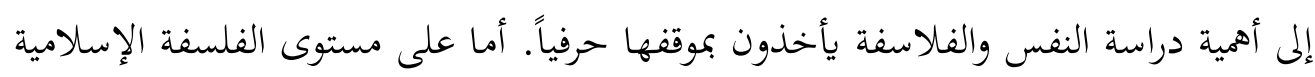

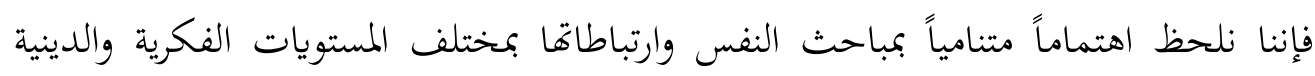
والسياسية والاجتماعية، حيث برز العديد من الفلاسفة المسلمين في الدراسات النفسية نتيجة تأثرهم بكل من التراث الفلسفي الإغريقي من جهة والأثر الديني الإسلامي من جهة. 
ومن هؤلاء الفلاسفة الكندي والفارابي وابن سينا والغزالي وغيرهم من فلاسفة المغرب العربي. ولذلك اخترت لبحثي هذا مفهوم النفس عند الكندي والفارابي وابن سينا والغزالي. وفي هذا البحث قمت باستخدام لمنهج التحليلي الموضوعي. وقد قسمت البحث إلى أربعة

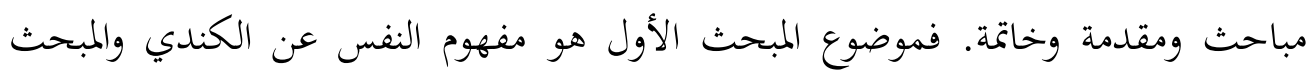
الثاني مفهوم النفس عند الفارابي والمبحث الثالث مفهوم النفس عند ابن سينا أما المبحث الرابع تناولت فيه مفهم النفس عند الغزالي. فلقد اهتم ابن سينا بدراسة النفس الإنسانية اهتماما كبيراً وصاغ منها نظرية حازت لهات على إعجاب الدرّاس، وأصبح المتحدث الرسمي والمعبر الأساسي عن الفلاسفة، فالباحثون يعتبرون رأيه ممثلاً لرأى الفلاسفة، ولذا نجد بعض الكاتحاتبين يقولون: قالت الفلاسفة..، وعند الفلاسفة..، واحتج الفلاسفة..، والمقصود واحد هو الشيخ الرئيس ابن سينا، وهذا ما نلمسه في كلام الإمام الرازي في أكثر من موضع في هذا الباب، فنراه يقول مرة ( أطبق الفلاسفة على الى

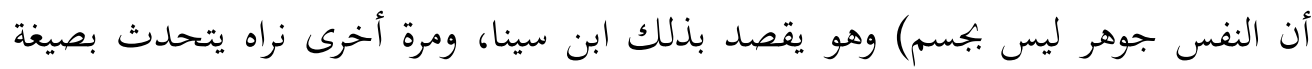
الجمع فيقول( قالوا كذا...) وهو يقصد بذلك - أيضاً- ابن سينا، وقد تنبه الدكتور إبراهيم

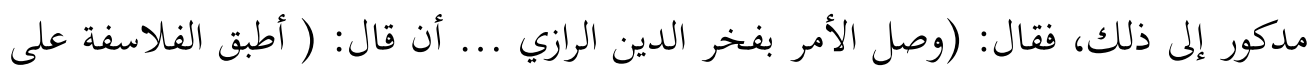

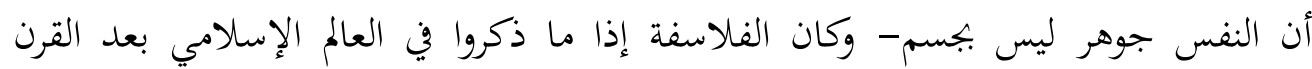
الخامس الهجري إنما يراد بهم ابن سينا) (1). ولقد اتفق كل من تناول الغزالي[505هـ/1111م] على علو مكانته في مجال المعرفة، ورسوخ قدمه فيها، وتميز إلى جانب الفقه والكلام والفلسفة والتصوف بخخبرته بعلم

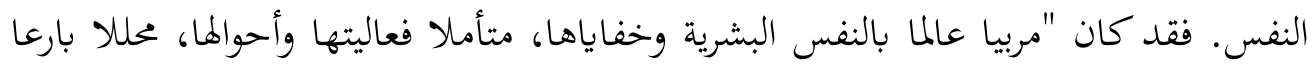
للسلوك وخلجات الضمير" (2). و يعد أبو حامد الغزالي أقرب مفكر إسلامي إلى الابتكار في معالجة موضوعاته برؤية علمية دقيقة، فهو في مشروعه الفكري خير من نظر إلى النفس الإنسانية من حيث دوافعها، وغرائزها، وكيفية السمو بها في مدارج الصلاح؛ لضمان سعادقا في الحال والمآل. 
و ذكر د.عبد الكريم العثمان أن الغزالي استطاع في "الإحياء" أن ينفذ إلى خفايا

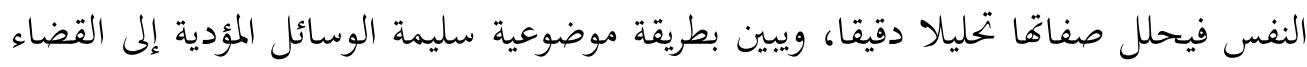
على الخلق المذّوم، واكتساب الخلق المحمود، بطريقة لم يسبق إليها (3). كما حاول أبو نصر محمد الفارابي (874 - 950) الفيلسوف من تركستان

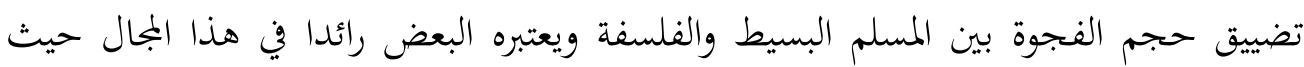

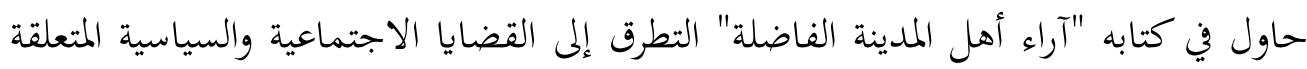

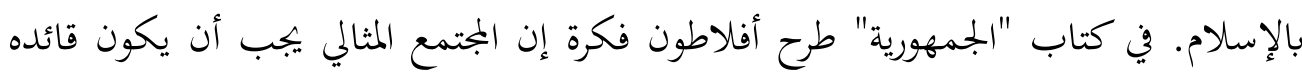

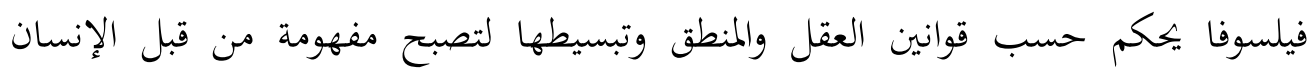

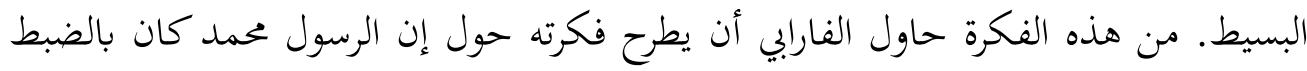

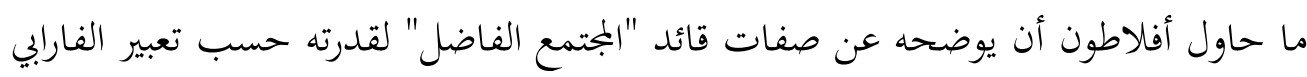
من تبسيط اللهم روحية عليا وإيصالها إلى الإنسان البسيط.

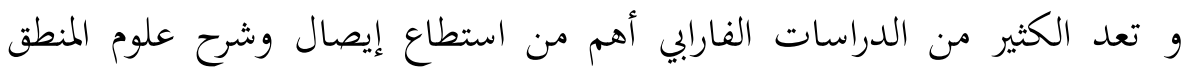

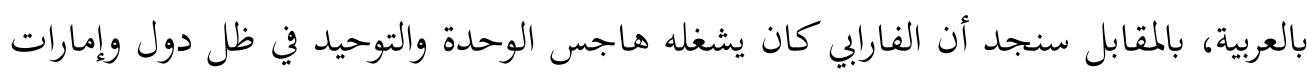

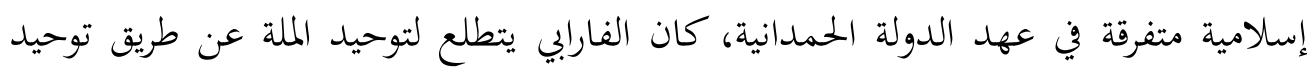

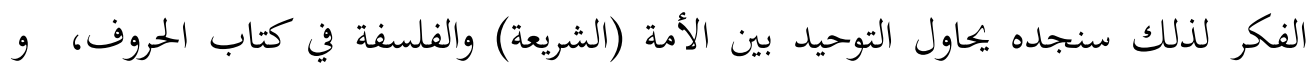

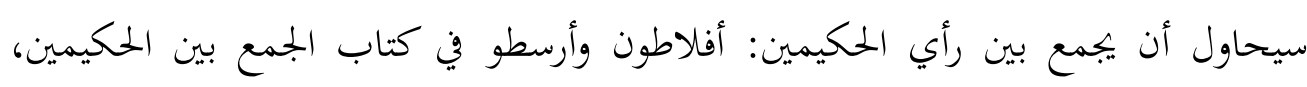

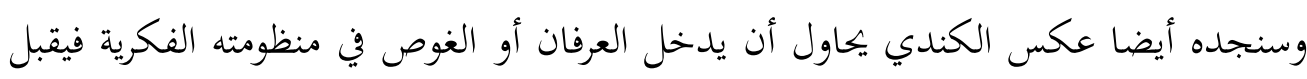

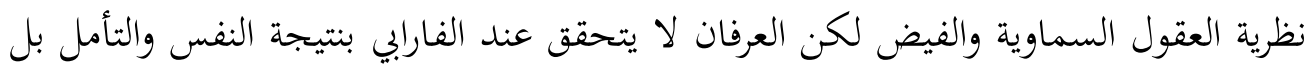

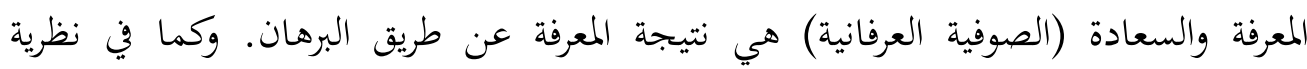

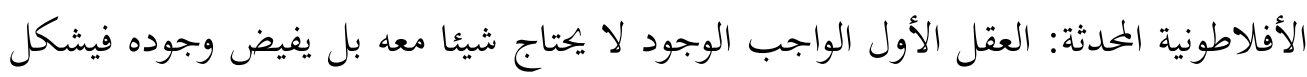

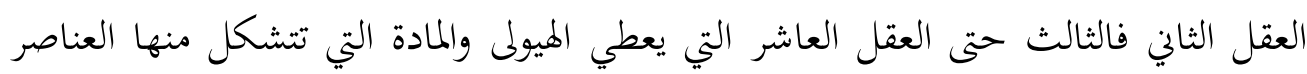

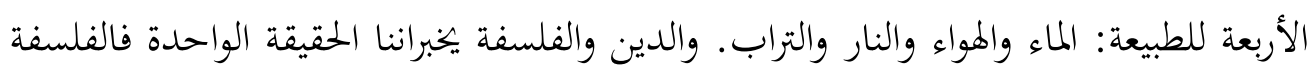

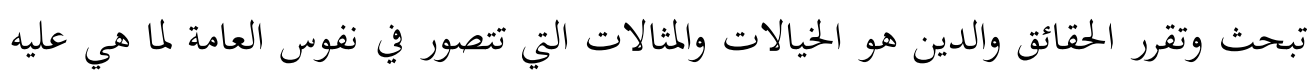

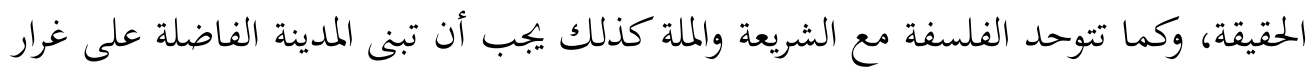


تركيب الكون والعالم بحيث تحقق النظام والسعادة للجميع. هذا كان حلم الفارابي المقتبس من فكرة المدينة الفاضلة لأفلاطون(4). ولثراء فكر العلماء الأربعة وغزارة مؤلفاقم وموضوعاقم المتعلقة بالنفس الإنسانية جمعت الدراسة بينهم. وفي الختام أسأل الله سبحانه وتعالى أن يوفقني بتحقيق ما أصبو إليه فهو حسبي عليه وإليه أنيب.

\section{قضية الدراسة:}

تعد الأزمة الفكرية أخطر ما أصابت الأمة العربية والإسلامية، سُدت بسببها سبل

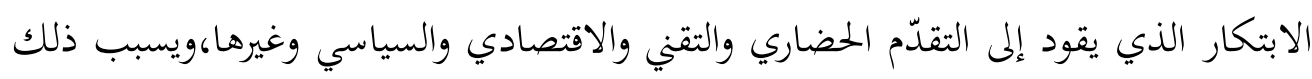

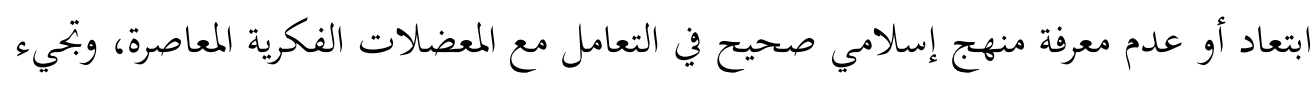

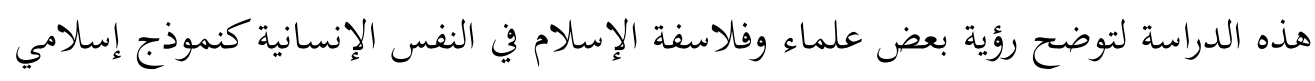

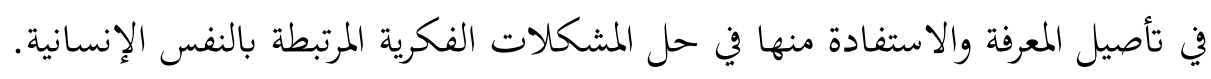
وإيماناً بأصالة وغزارة فكر فلاسفة الإسلام (الكندي ابن سينا - الفارابي - الغزالي)

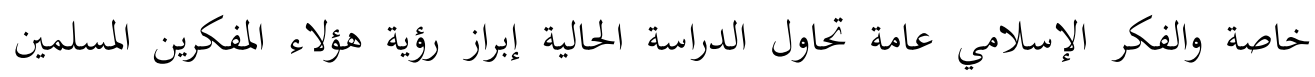
للنفس الإنسانية.

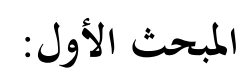

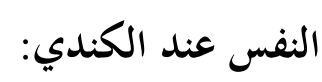

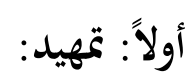

أبو يوسف يعقوب بن إسحاق الكندي(5) فيلسوف العرب وأول فلاسفة الإسلام

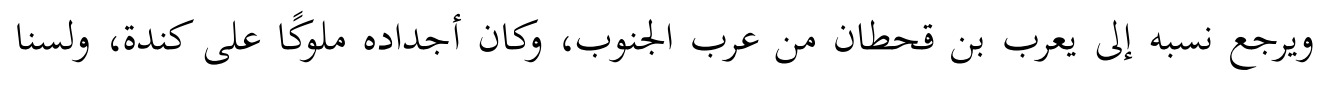

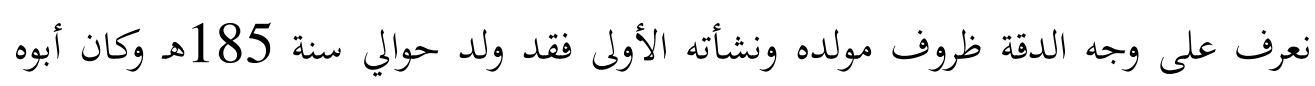

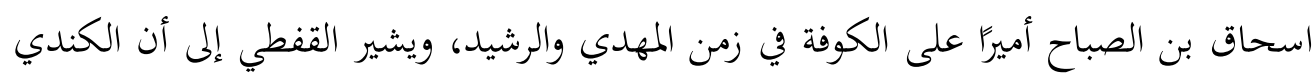

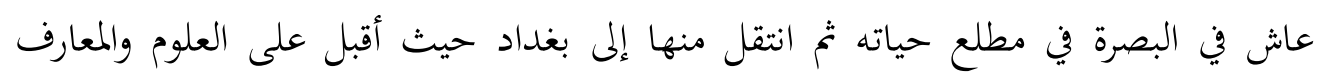




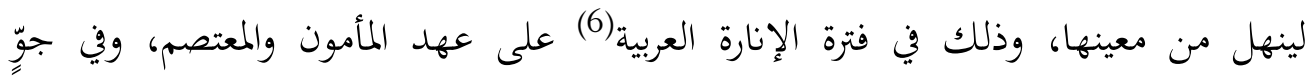

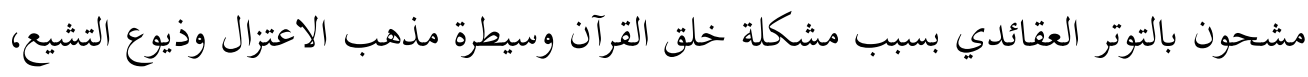

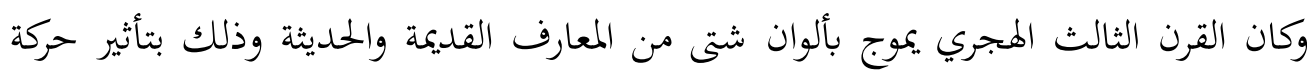

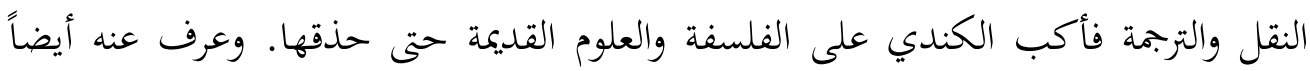

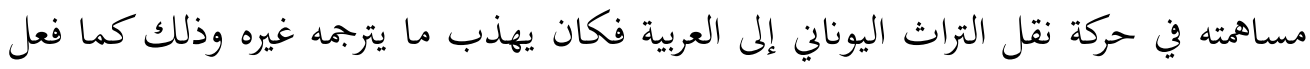
بكتاب أثولوجيا أرسطو طاليس. وكان له نفر من التلاميذ يقومون بالترجمة تحت إشرافه؛

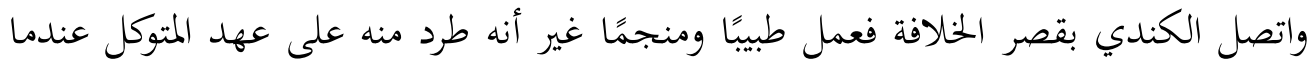

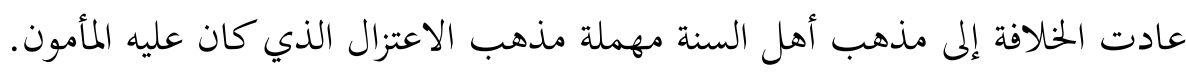
(أ) تعريف النفس:

يعرّف الكندي النفس في رسالة "حدوث الأشياء ورسومها" بأغها "تمامية جرم طبيعي ذي آلة قابلة للحياة" أو "استكمال أول لجسم طبيعي ذي حياة بالقوة" وهذان التعريفان

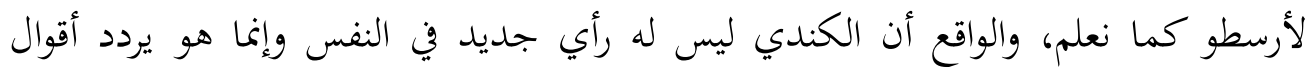

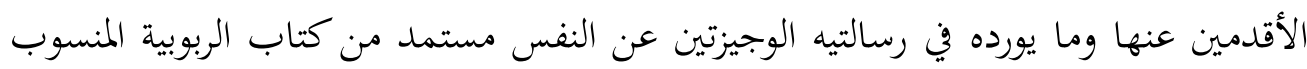

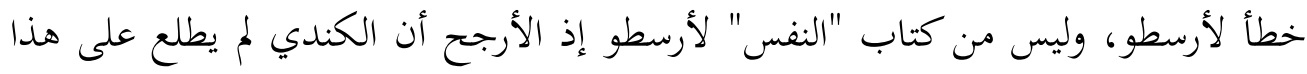

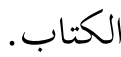

و إلى جوار التعريفين الأرسطيين السالفين نجد عند الكندي تعريفًا ثالثًا يظهر فيه

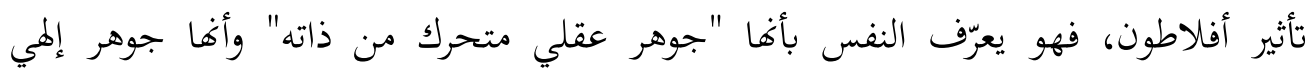

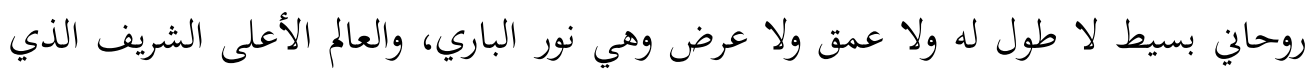

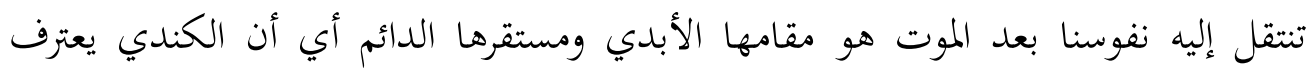
صراحة بخلود النفس لكنه لا يذكر هل وجدت فيه قبل البدن كما يقول أفلاطون أم أهما

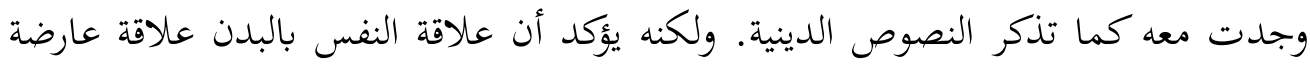

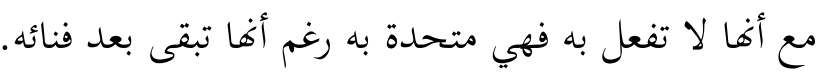

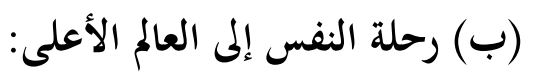


و تختلف النفوس من حيث وصولها إلى المستقر الأعلى، فمنها ما يكون في غاية النقاء فيخلص إلى العالم الشريف ساعة مفارقته للبدن، ومنها ما فيه دنس وأشياء خبيثة فيقيم في كل فلك من الأفلاك مدة من الزمان حتى يتهذب وينقى ويرتفع إلى فلك كوكب أعلى،

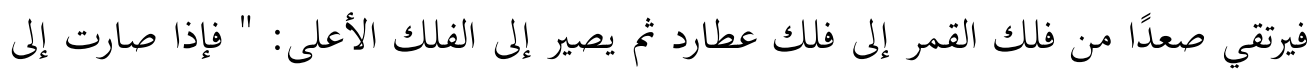
الفلك الأعلى ونقيت غاية النقاء وزالت أدناس الحس وخيالاتها وخبثها منها، ارتفعت إلى عالم العقل وطابقت نور الباري. وفوض إليها الباري أشياء من سياسة العالم تلتذ بفعلها والتدبير

و كان الكندي متأثرًا بمذاهب الصابئة، والفلسفة اليونانية، والإسكندرانية، التي ترى بوجود صلة بين العالمين العلوي والسفلي، عالم السماء والأرض، وهي صلة العلة الفاعلة بالمعلول (8) و يذكرنا هذا الترقي التدريجي للنفس عبر أفلاك الكواكب بالجدل الصاعد عند أفلاطون، غير أن رحلة النفس هنا تتخذ الكواكب الحية العاقلة محطات روحية فترسم بذلك الطريق الذي سيشير إليه الفارابي فيما بعد في نظرية فيض عقول الكواكب عن واجب الوجود، وكان المؤرخون قد ظنوا أن الفارابي هو أول من أشار إلى نظرية العقول العشرة من الإسلاميين ولكن الكندي - كما تبين لما - هو الذي وضع الخطوط الأولية لهذه النظرية او أنه قد تلقاها من التراث اليوناني وعرضها بصورة أولية ساذجة وجاء الفارابي فأحكم إخراجها على الصورة التي نجدها بها في المدرسة المشائية الإسلامية.

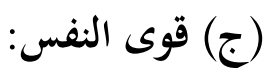

يشير الكندي إلى أن النفس الثلاثية كما أوردها أفلاطون، وكان أرسطو قد اعتقد خطأ أن أفلاطون يقر بثلاث نفوس متمايزة مما يهلد وحدة النفس، ولكن الواقع ان أفلاطون قد تكلم عن نفس واحدة لها ثلاث قوى هي: القوة الغضبية والقوة الشهوانية والقوة العقلية

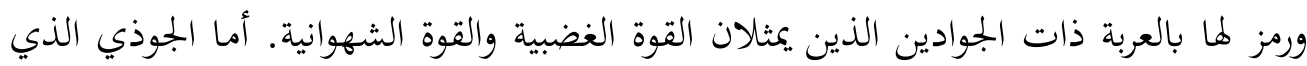
يشد أعنة الجوادين فهوى يرمز إلى القوة الناطقة. وقد أدرك الكندي حقيقة الموقف الأفلاطوني وكيف أنه يشير إلى النفس كجوهر روحاني بسيط له قوى ثلاث، وجميع هذه القوى تتعلق 
بالنفس "ومنها ماله آلة أولى مشتركة بين الحس والعقل وهي الدماغ موضع جميع القوى

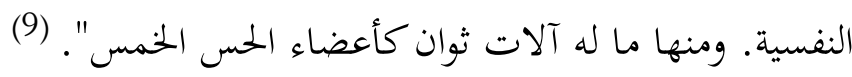
و يذكر الكندي في موضع آخر من رسائله أن في النفس قوتين متباعدتين هما: الحسية والعقلية وبينهما قوة أخرى متوسطة هي القوة المصورة والغاذية والنامية والغضبية والشهوانية. 1- القوة الحاسة: وهي التي تدرك صور المحسوسات في مادتا. وينصب إدراكها على الصور الجزئية وليست لما القدرة على تركيب الصور التي تدركها، وأما آلاتها هي الحواس الخارجية الخمس.

2- القوة المتوسطة: ومنها القوة المصورة أي: المتخيلة وهي القوة التي توجد صور الأشياء

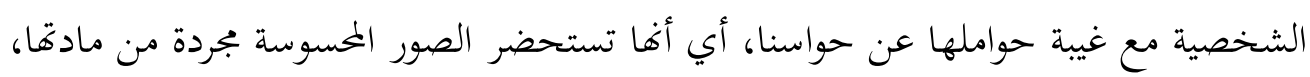

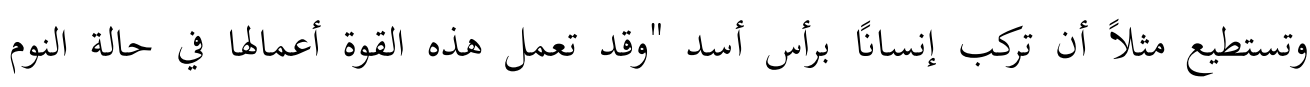
واليقظة".

و الحفظ أي القوة الحافظة من القوة المتوسطة فهي تقبل الصور التي تؤديها إليها

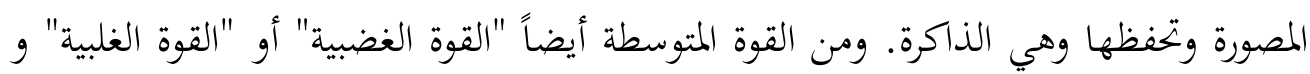

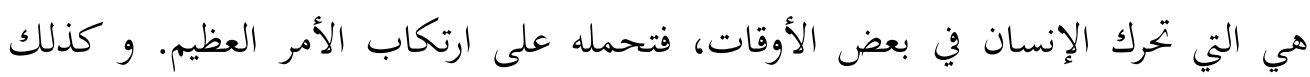
"القوة الشهوانية" وهي التي تتوق في بعض الأوقات إلى بعض الشهوات، وأخيرًا القوة الغاذية و القوة المنمية. 3- القوة العاقلة: وهي التي تترك المجردات أي صورة الأشياء بدون مادةما. وموضوعات إدراكها على نوعين: المبادئ العامة كقانون العلية وقوانين الفكر الأساسية، وكذلك الأنواع إعرداء والأجناس وليس الأشخاص أو الجزئيات. (10) ورسالة الكندي في العقل تلقي الضوء على موقفه من مشكلة الإدراك العقلي وهو في هذه الرسالة متأثر بأرسطو وشراحه ولا سيما الإسكندر الأفروديسي وهو يقسم العقل في هذه فئه

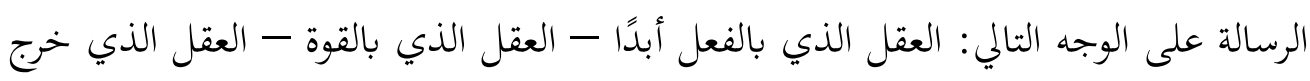


في النفس من القوة إلى الفعل - العقل الظاهر. فالعقل - على هذا النحو - واحد يوجد في

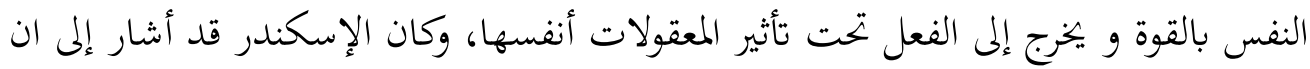
العقل الفعال هو الذي يخرج العقل من القوة إلى الفعل، وتبعه في لك الفارابي والإسلاميون.

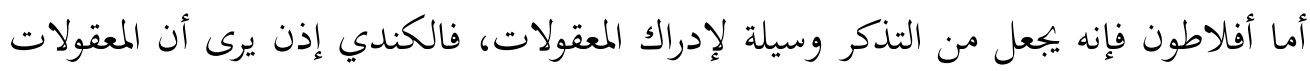

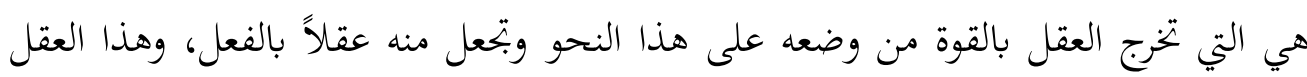

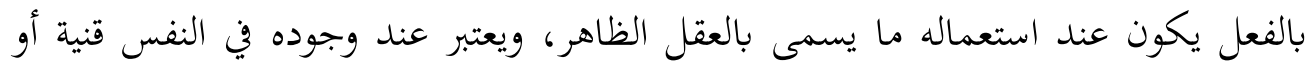

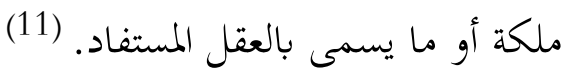

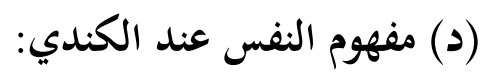

أحدث الكندي تغييرًا في النظرة العربية الإسلامية في مفهوم النفس، فاستبعد النزعة

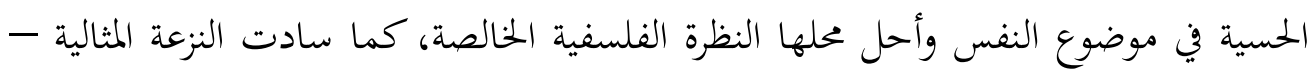

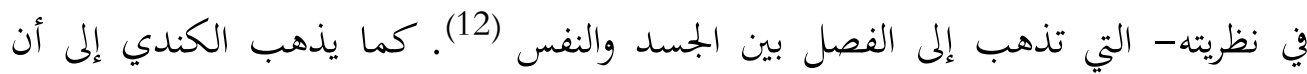

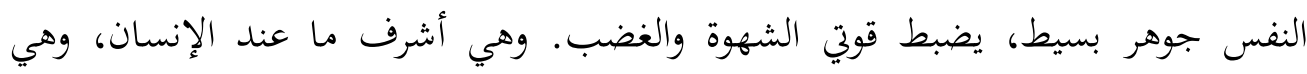
النفس الناطقة. وأهما - أي النفس - إذا تجرد صاحبها من الماديات، وأكب على النه التأمل والبحث، تتجاوز حدود البدن في المعرفة، وتتجاوز حدود العالم الخسوس؛ فتعلم الحقائق

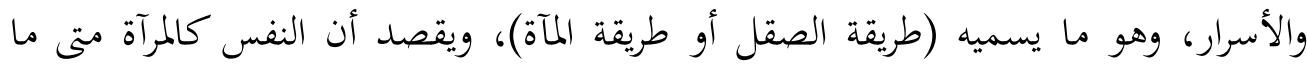
صقلت عن طريق التأمل والتجرد ظهرت لها صور المعلومات وانكشف لها لهائة الحقائق والأسرار (13). كما يرى الكندي أن التأمل النظري يخلص النفس من سلطان الماديات، ليغمرها العقل

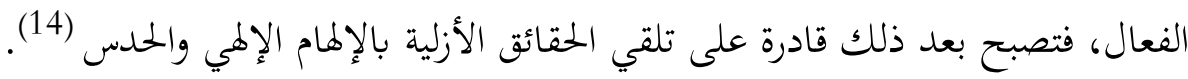

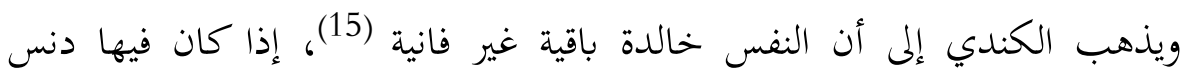
وخبث فإنها بعد مفارقة البدن تقيم في فلك القمر، ثم تتنقل بين أفلاك الكواكب من الأدنى

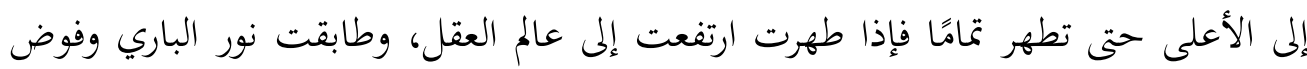
لها أشياء من سياسة العالم (16). النوم والرؤى: يعرف الكندي النوم بقوله: "النوم هو ترك استعمال النفس للحواس النقاس

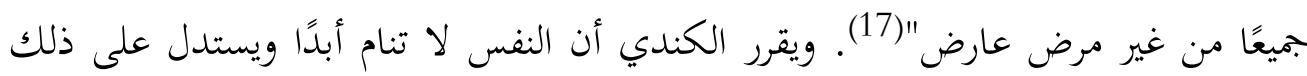


بأنه في حال نوم الجسلد، يرى الإنسان من عجائب الرؤى والأحلام على الرغم من توقف

$$
\text { الحواس عن العمل (18). }
$$

و يُرجع الكندي الرؤيا إلى قوة من قوى النفس متوسطة بين الحس والعقل هي

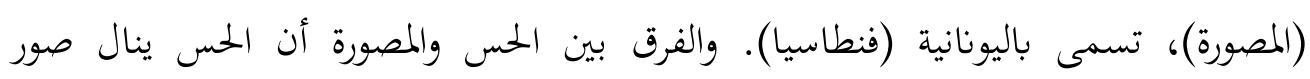

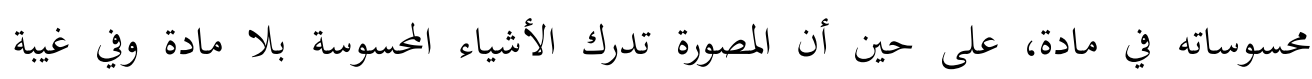
المخسوسات (19). 


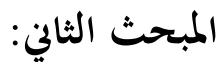

مفهوم النفس عند أبو نصر الفارابي (المعلم الثاني):

أولاً: تمهيد:

مذهب الفارابي في النفس يشبه - إلى حد ما - مذاهب اليونان من حيث أفم كانوا

يرتبون النفوس بحسب مراتب الوجود فللعالم نفس ولكل سماء نفس ثم للإنسان نفس وللحيوان الفيان

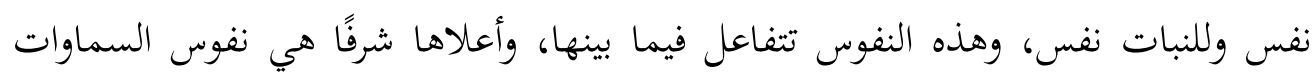

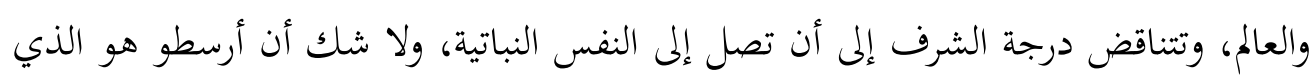
وضع الصيغة النهائية لترتيب النفوس بحسب ما ذكرناه.

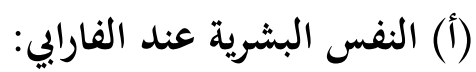

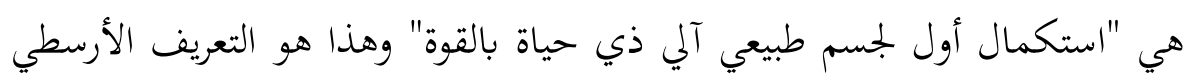

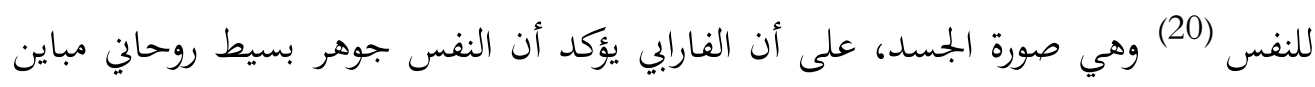

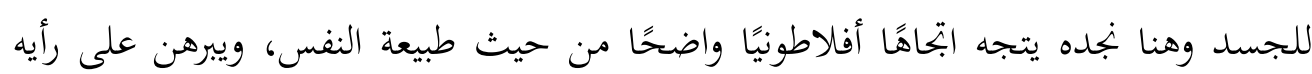
هذا بأدلة ذات طابع أفلاطوني في جملتها منها:

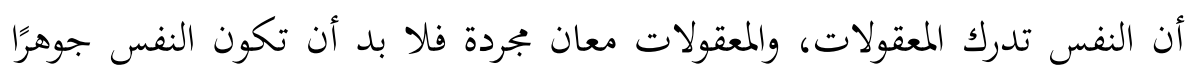

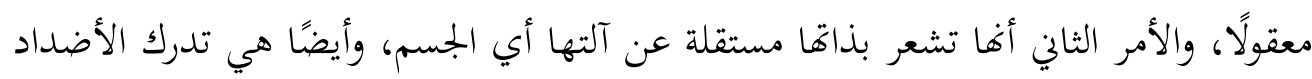

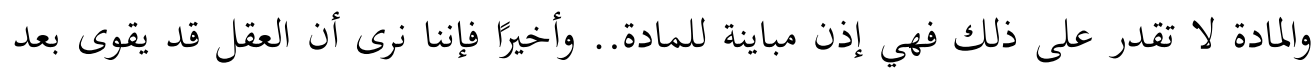

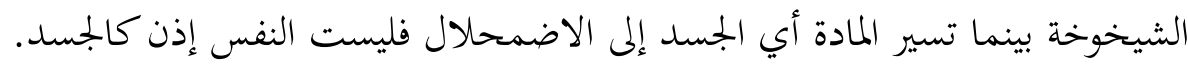

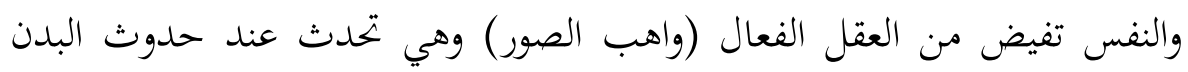

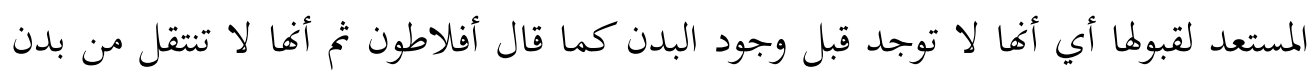

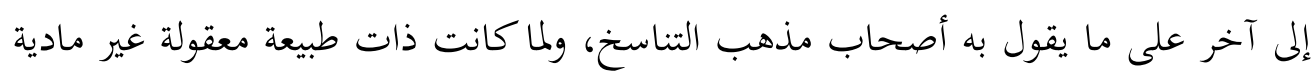

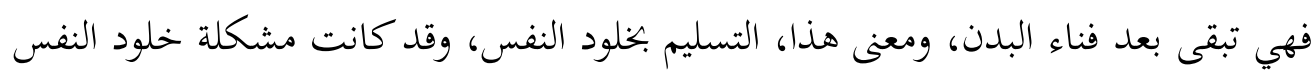

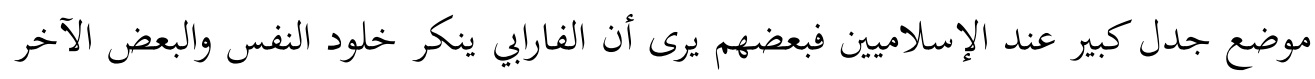




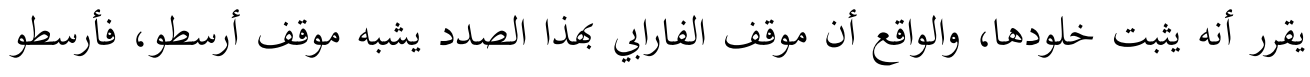
يذكر في كتاب (النفس) أن الذي يفسد في النفس هي القوى المتعلقة بالبدن وغرائزه، أما

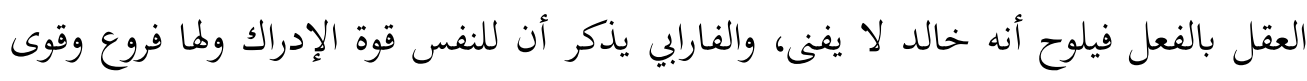

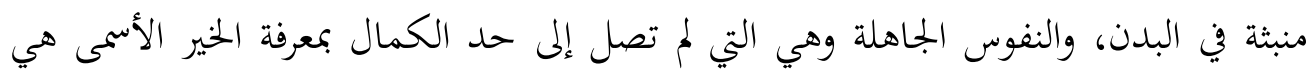

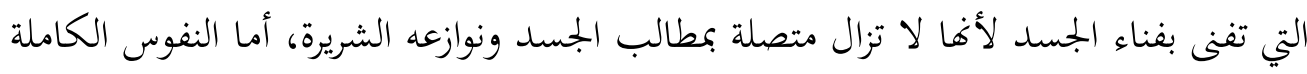

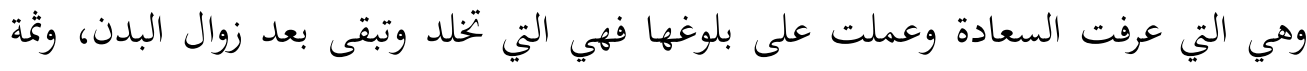

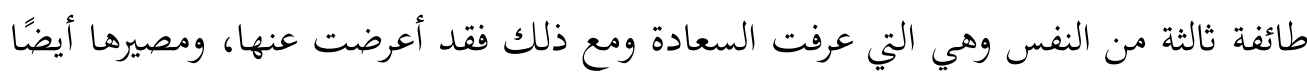
كمصير النفوس الجاهلة الشقية (21).

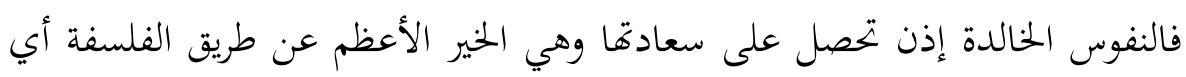

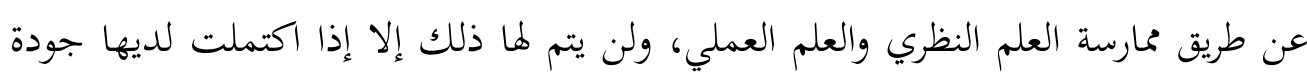

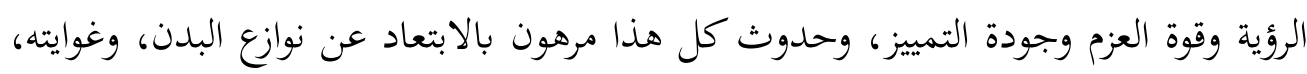

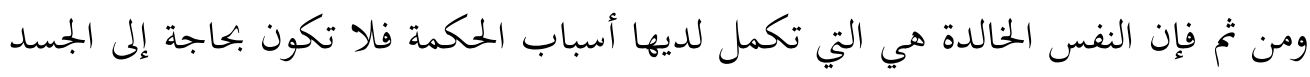

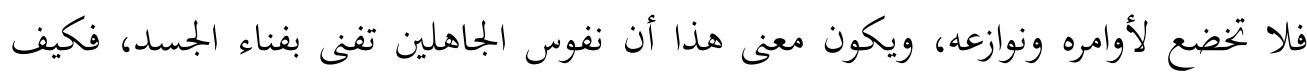

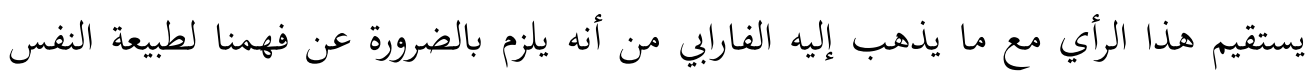

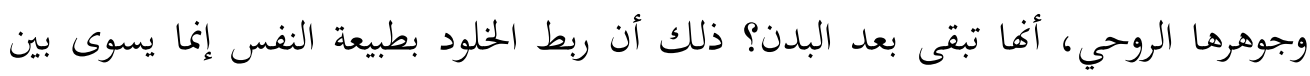
النفوس في مصيرها: الكاملة منها والجاهلة الفاسقة.

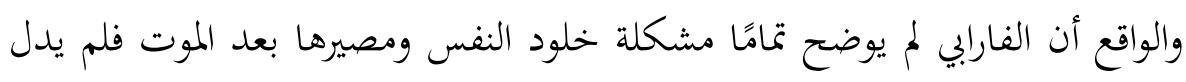

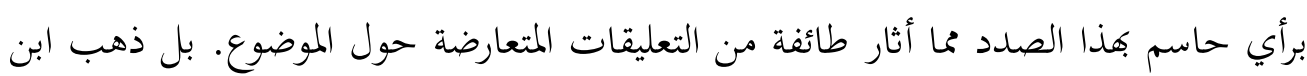

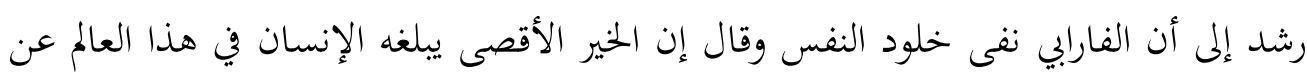

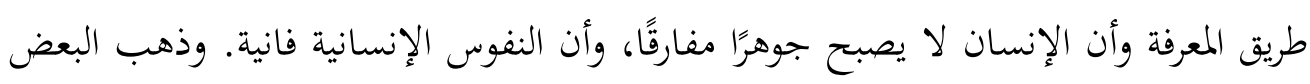

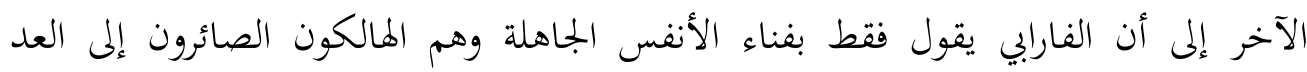

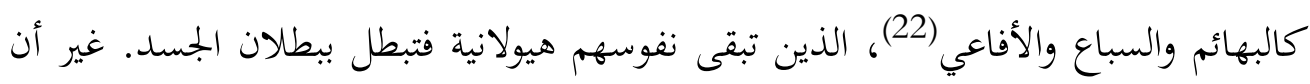

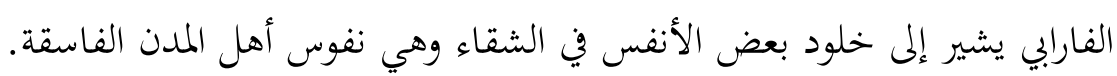


ومع هذا يمكنا التمييز بين ثلاثة أنواع من النفوس إذا استبعدنا الرأي القائل بفناء

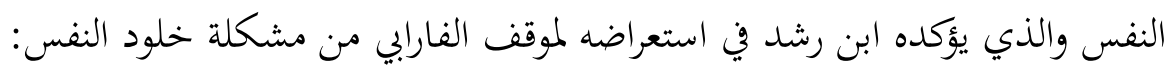

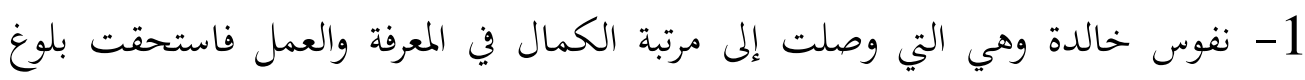
السعادة والخلود فيها.

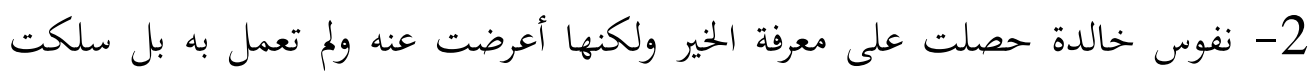
طريق الغواية وهذه النفوس الفاسقة تخلد في الشقاء لأهما لم تربط بين المعرفة والسلوك. 3- نفوس فانية وهي النفوس الجاهلة التي لمتعرف الخير ولم تسع إليه فبقيت بحالتها لفئ الميولانية ففسدت بفساد الجسد ويكون مصيرها الفناء التام.

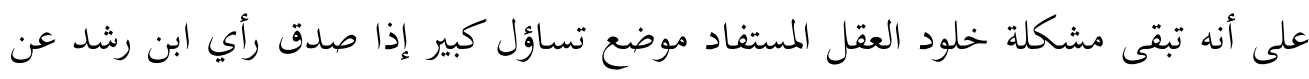

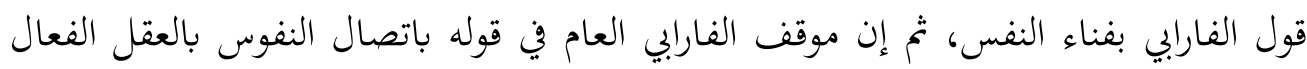

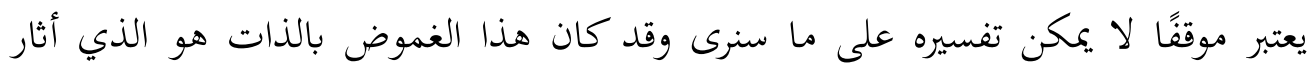
مشكلة العقل الفعال عند شراح أرسطو كما ذكرنا. (ب) قوى النفس: ملفي الفعل

\section{للنفس قوى متعددة، منها قوى محركة وأخرى مدركة.}

أ) والقوى المحركة منها القوى المنمية وهي النفس النامية عند أرسطو وتوجد في النبات والحيوان ماندان

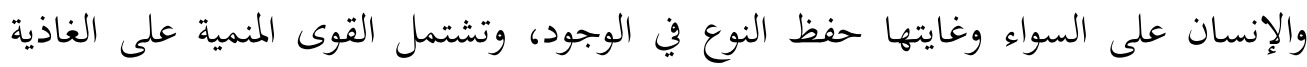
والمربية والمولدة. والقوى النزوعية أيضًا من القوى المحركة، وهي إما شهوانية تسعى وراء الصالح المفيد أو غضبية تبتعد عن الضار المؤم (23). ب) وأما القوى المدركة في النفس فمنها القوى الحساسة وهي تشتمل على الحواس الخارجية

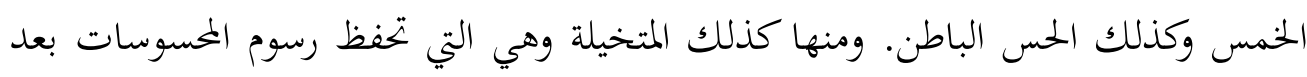

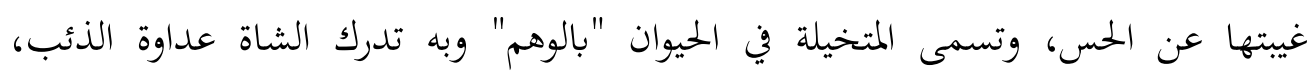


وتسمى عند الإنسان بالمفكرة وهي تؤلف تركيبات من عناصر محفوظة مطابقة للواقع أو غير مطابقة له. وبعد المتخيلة نجد الحس المشترك وهو الذي يتقبل المحسوسات ويحفظها كما تحفظ الذاكرة

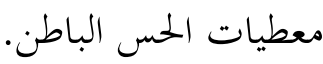

وهذه القوى النفسية المتعددة التي أشرنا إليها لا تمدد وحدة النفس إذ أن النفس

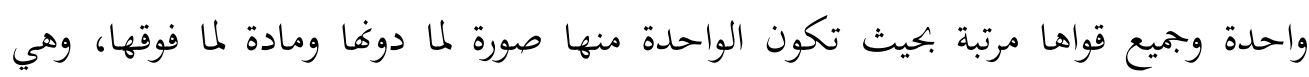
مرتبطة بالجسد أشد الارتباط، فالنفس إذا لم يوجد جسد مستعد لقبولها لا يتهيأ لها الوجود أصلاً، والجسد أشبه بمدينة يقوم على كل قسم منها رئيس خاضع للرئيس الأعلى وهو القلب. وأخيرًا نجد القوة الناطقة وهي التي تعقل المعقولات وتميز بين الجميل والقبيح وبها يتم تحصيل الصناعات والعلوم. وللناطقة قوتان: قوة نظرية تحصل المعرفة وأخرى عملية يتم بها تحصيل الصناعات والمهن. والعقل النظري على مراتب: العقل الهيولاني والعقل بالملكة، والعقل المستفاد. 1- أما الهيولاني أو العقل بالقوة فهو قوة من قوى النفس مستعدة لانتزاع ماهيات الأشياء

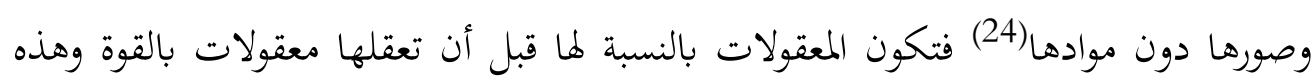
القوة تقابل العقل المادي عند الكندي والاسكندر الأفروديسي.

2- العقل بالملكة أو العقل بالفعل، وهو العقل الذي يتم فيه نقل المعقولات بالفعل، فإذا

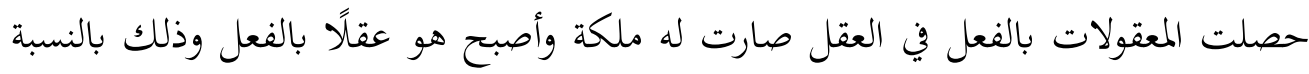

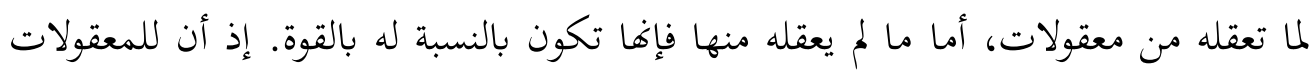

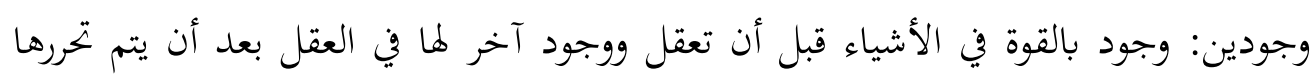
بالكلية عن علائق المادة.

3- العقل المستفاد: وحينما تصبح المعقولات قائمة في العقل بحيث يدركها كما لو كانت غير

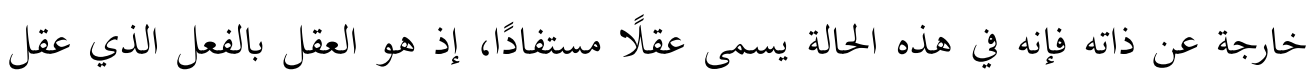
المعقولات المجردة، وأصبح في استطاعته أن يدرك الصور المفارقة أي تلك التي لم تكن في مادة 
أصلا كالعقول السماوية، وما كان العقل المستفاد في غنى عن المادة اطلاقًا بعكس الهيولاني

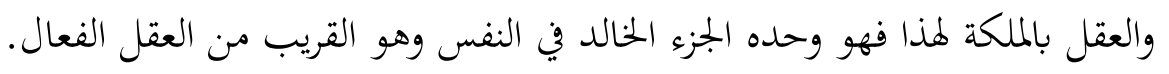

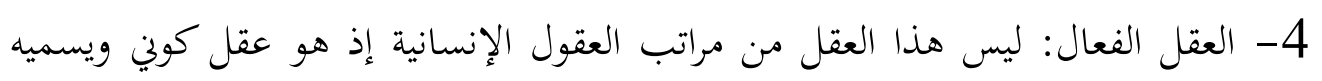

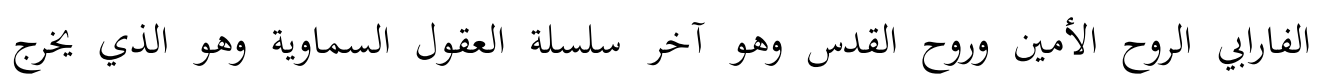

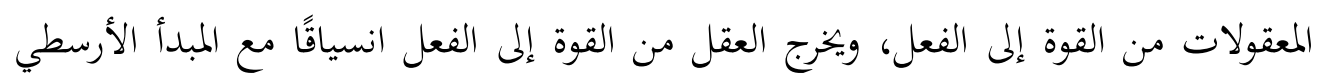

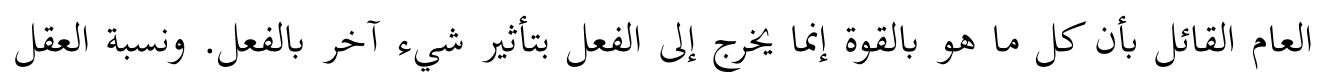

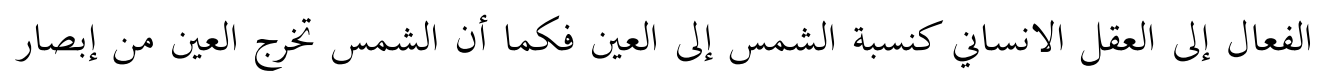

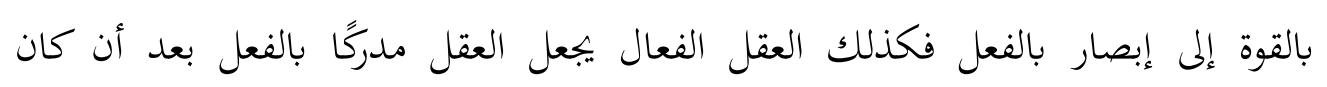
بالقوة)

والفارابي يسمي العقل الفعال "واهب الصور)، ويقصد بذلك أن هذا العقل يشتمل

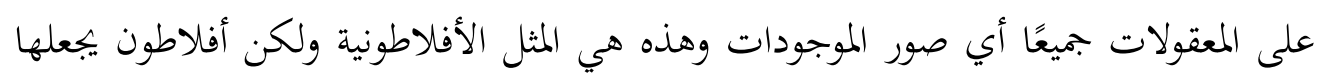

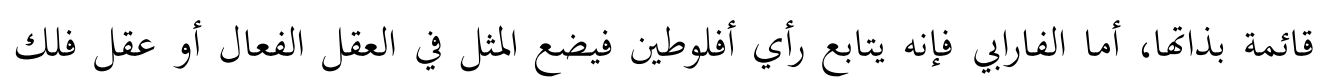

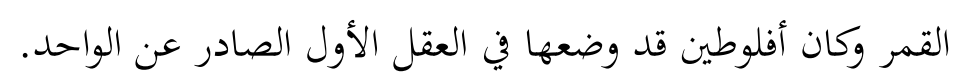

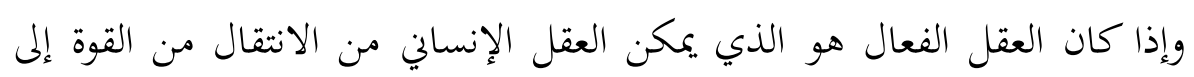

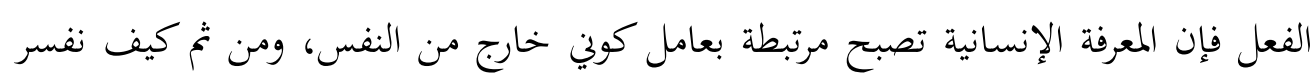

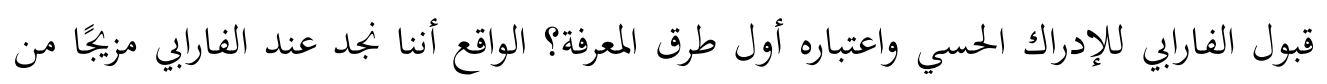

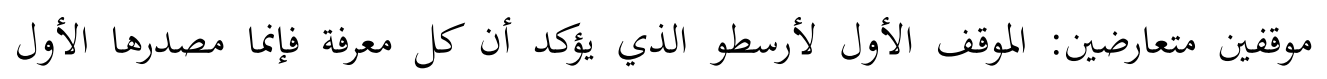

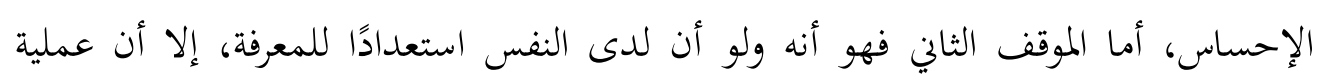

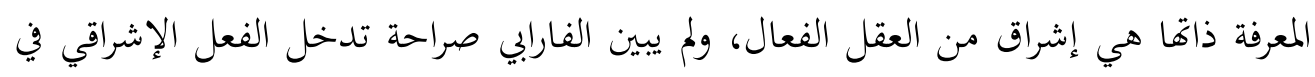

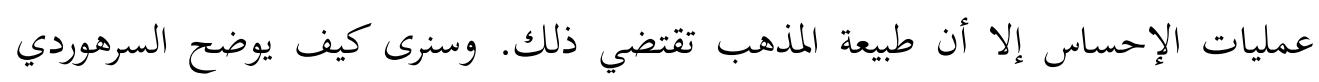

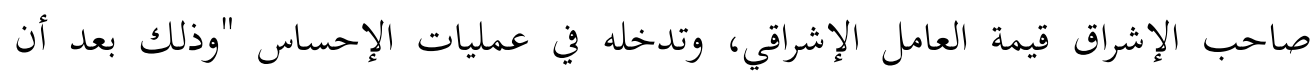
تكتمل للمذهب الإشراقي أسباب الظهور".

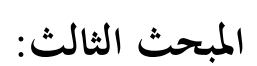




\section{النفس عند الشيخ الرئيس ابن سينا:

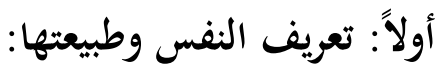

يعرف ابن سينا النفس بأها كمال أول لجسم طبيعي آلي ينمو ويتغذى. ويلاحظ على هذا التعريف أنه ينطبق تمامًا على تعريف أرسطو للنفس في كتابه المسمى "بالنفس" وقد الند

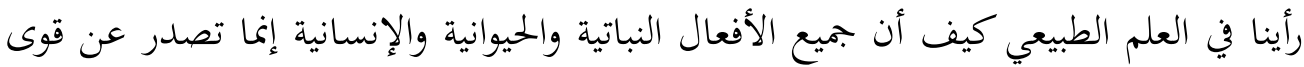
زائدة على الطبيعة الحسية، وهذه القوى - كما رأينا - هي التي يستكمل بها النبات والحيوان التيان والإنسان وجوده، وتسمى هذه القوى (كمالات) بالنظر إلى أها تكمل الجنس فيصير بها نوعًا

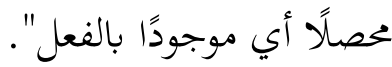
وتعريف ابن سينا للنفس (بأها كمال) إنما يرجع إلى أن النفس تعد كمالًا من جهة

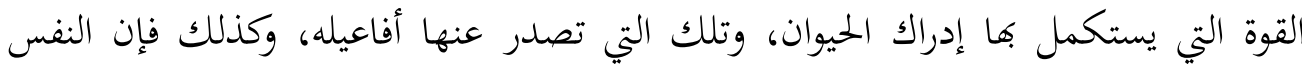
المفارقة (كمال)، والنفس - التي لا تفارق - كمال بهذا المعنى (26).

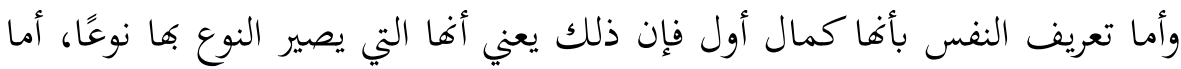

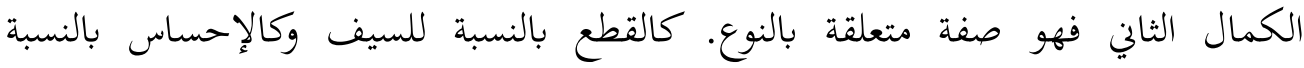
للإنسان. والنفس كمال أول للجسم. بمعنى أها كمال لجنس الجسم لا لطبيعته المادية أما

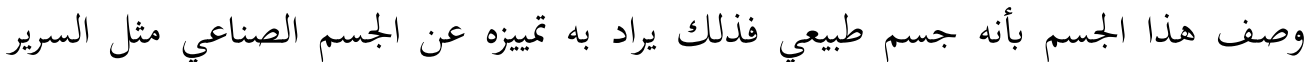
والكرسي والحائط. وكذلك فإنه ليس أي جسم طبيعي بلهو جسم طبيعي تصدر عنه كمالاته

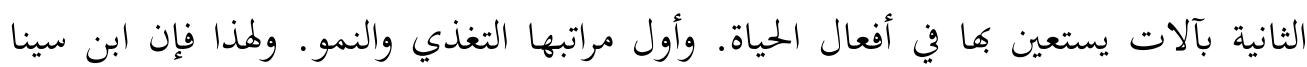
يصف هذا الجسم الطبيعي بأنه جسم يتغذى وينمو، وهو يشير بذلك إلى النبات. أما الحيوان

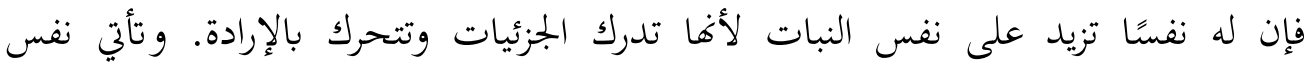

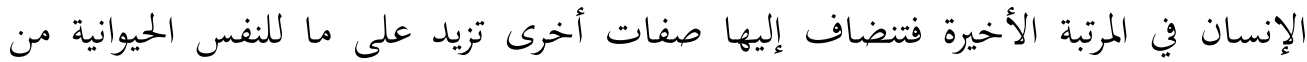
صفات ويعرفها ابن سينا: "بأها كمال أول لجسم طبيعي آلي من جهة ما مان يفعل الأفعال الكائنة بالاختيار الفكري والاستنباط بالرأي، ومن جهة ما يدرك الأمور الكلية"(27).

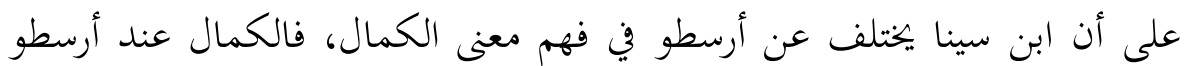

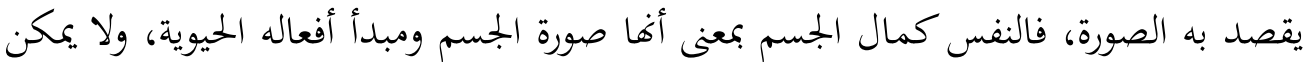


لها أن توجد بدون الجسم إذ هو مادتّا وقوامها. أما ابن سينا فيرى أنه إذا كانت كل صورة

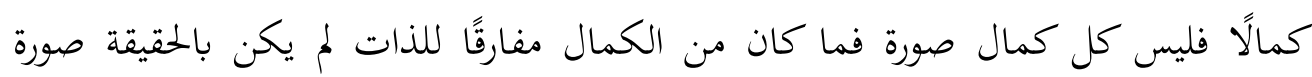
للمادة وفي المادة، فإن الصورة التي هي في المادة هي الصورة المنطبعة فيها القائمة بها(28). وإذن فابن سينا يرى أن وصف النفس بأها كمال لا يعني أها صورة بل يعني أها

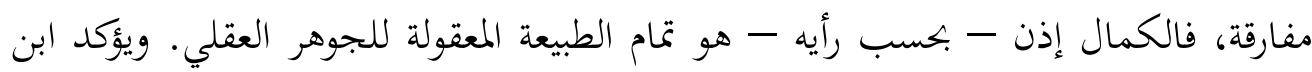
سينا أن النفس غير البدن وأهما تتميز عنه من حيث أهما جوهر عقلي يمكن أن توجد مفارقة

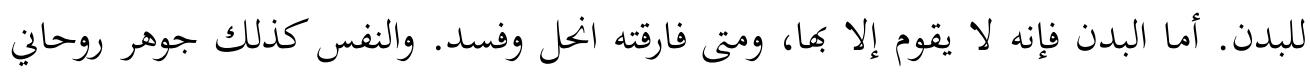

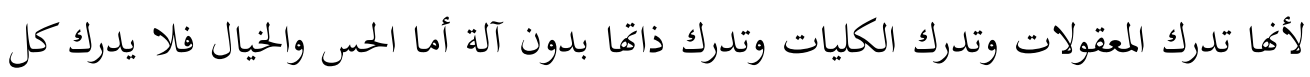

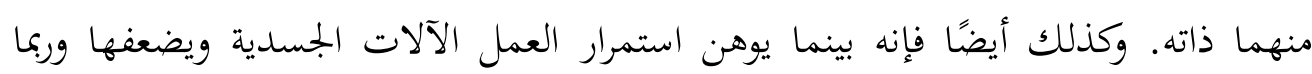

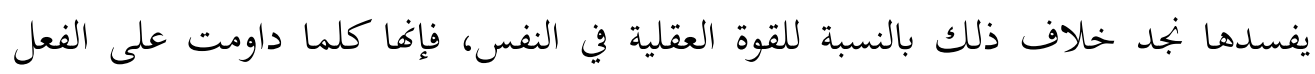
وتصور الأمور وممارسة المسائل العقلية كلما ازدادت صقلاً واكتسبت قوة وصارت تنقل بلانل

$$
\text { المعقولات بعد ذلك بسهولة أكبر. }
$$

ويلاحظ أنه بينما تضعف آلات الجسد عند سن الأربعين نجد أن القوة العقلية على لى العكس منها تزداد قوة بعد هذه السن. فالنفس إذن ليست كالبدن بل هي جوهر روحاني (29). وربما استطعنا تفسير قوله هذا على ضوء النظرية المشائية التي تذهب إلى أن النفوس الجزئية إنما تفيض عن النفس الكلية التي تفيض بدورها عن العقل الفعال وهو عقل فلك القمر

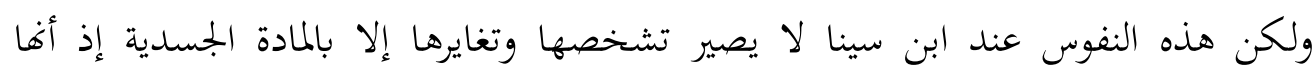
واحدة من حيث الصورة، فتكون النفس الجزئية لزيد أو لعمر، فكيف يستقيم هذا مع إشارة ابن سينا إلى أها نزلت مكرهة في البدن وسجنت - كما يذكر في رسائله الصوفية الرمزية - ثيم إنه كيف يمكن القول أيضًا بالحنلود أي بأبدية النفس مع القول بحدوثها؟ الحق أننا لا نستطيع تفسير موقف ابن سينا من مشكلة أصل النفس وطبيعتها إلا إذا افترضنا وجود موقفين لديه بله بلهيه هذذا الصدد: موقف مشائي يفترض وجود النفس عند وجود البدن المستعد لقبولها، وموقف

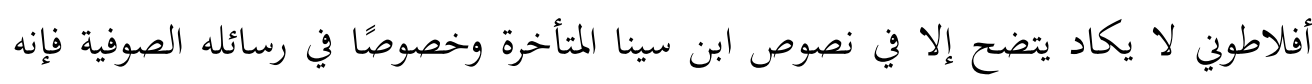


يذهب فيها إلى القول بوجود النفس مفارقة قبل وجود البدن، مع الحرص التام على عدم الانزلاق إلى التصريح بقدهما وذلك مخافة من نقض دعاوى الدين، وبالرغم من أن حل مشكلة مصير النفس عن طريق القول بالخلود سواء كان للنفس ككل أو للنفوس الفردية إنما يثير في نفس الوقت مشكلة أصل النفس وقدمها ويشير إلى ضرورة التسليم منطقيًا بموقف أفلاطون القائل بوجودها قبل البدن: إذ أن القول بوجود أبدي يفضي بنا الضرورة إلى التسليم بوجود أزلي. والحق أن هذا الغموض الذي استحكمت حلقاته حول مشكلة النفس عند مفكري الإسلام إنما يرجع إلى محاولاقم التوفيق بين مذاهبهم الفلسفية وموقف الدين. فنجد السهروردي مثلًا على الرغم من أفلاطونيته الواضحة يقع في نفس الخطأ ويذكر في "هياكل

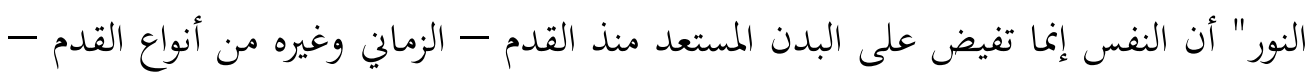
لقبولها. وقد يكون حل المشكلة بطريقة حاسمة في نطاق مذهب إسلامي أن نعود إلى التغريق الذي استخدمه ابن سينا في حل مشكلة قدم العالم وهو التفريق بين القدم الزماني وغيره من لعن أنواع القدم ولكن مع استبعاد القول بأن النفس تحتاج إلى البدن لكي توجد. 2- البراهين الدالة على وجود النفس: يستعرض ابن سينا مجموعة من الأدلة لإثبات وجود النفس منها:

$$
\text { 1- 1 - 1 البرهان الطبيعي: }
$$

ونجد هذا البرهان عند كل من أفلاطون وأرسطو ويقدم ابن سينا لهذا البرهان بتقسيمه المهان للحركة إلى نوعين: حركة قسرية، وحركة إدارية، وتصدر الحركة القسرية عن محرك خارجي يدفع

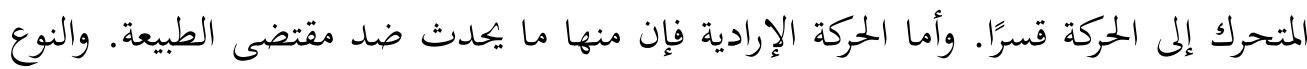
الذي يحدث على مقتضى الطبيعة هو كسقوط الحجر من أعلى إلى أسفل، أما النوع الذي

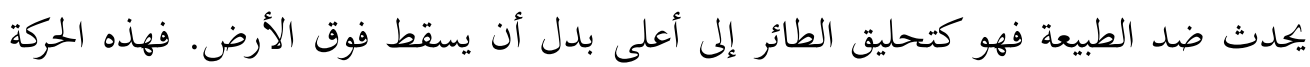

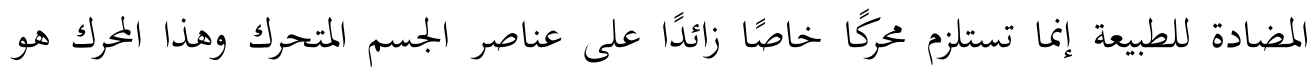
النفس (30). 
وكذلك تدلنا أفعال الكائن الحي من تغذ ومنو وتوليد وإحساس وحركة بالإرادة، على

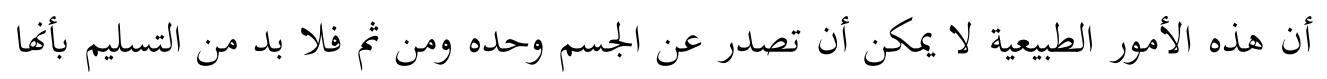

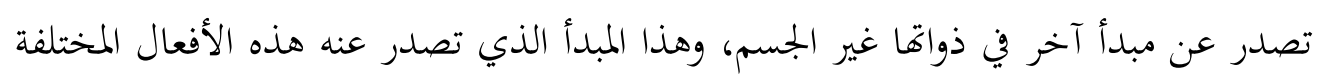

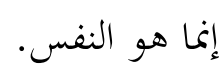

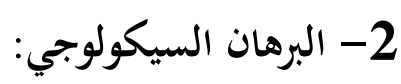

يقوم هذا البرهان على إثبات وجود النفس الإنسانية من ملاحظتنا لانفعالاتما

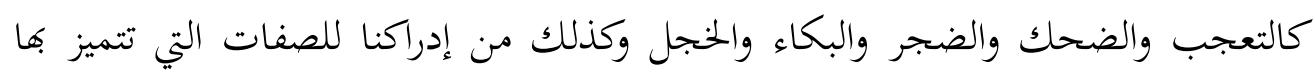

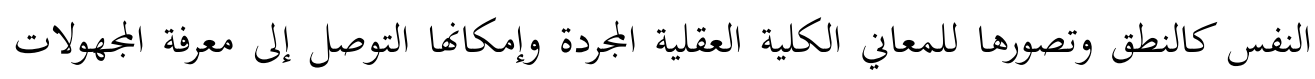

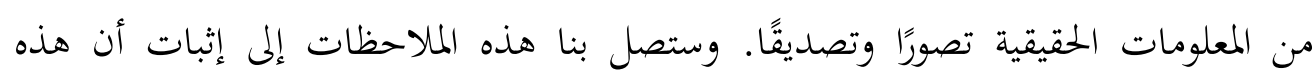

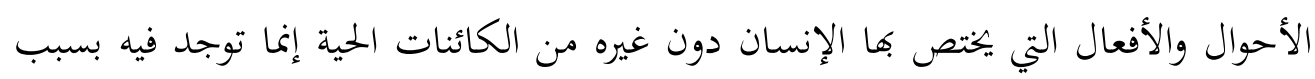
النفس. فللإنسان المدرك قوة يتميز بها عن الكائنات غير المدركة وهي النفس.

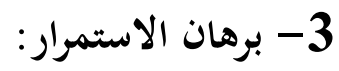

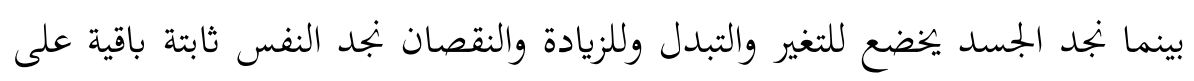

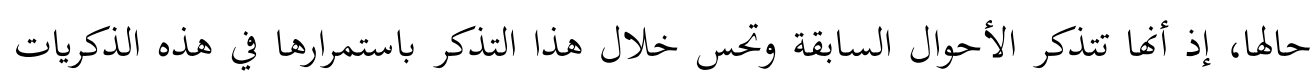

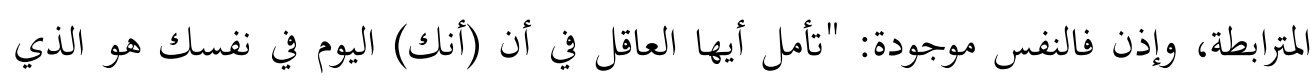

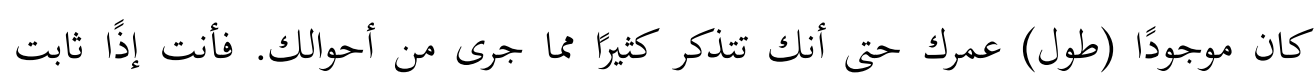

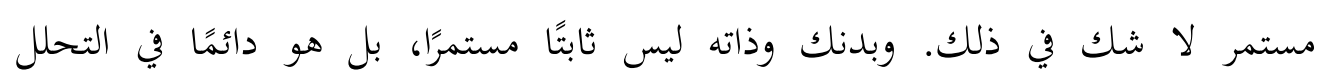

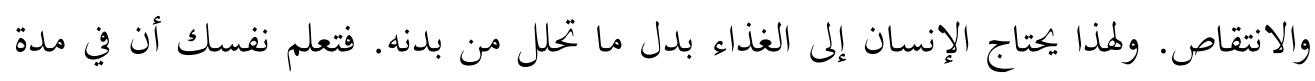

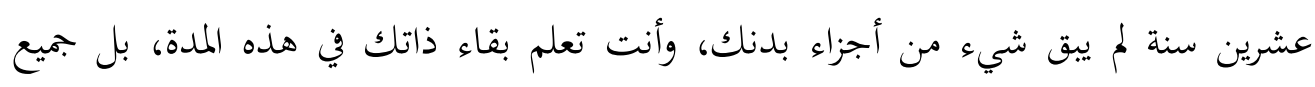

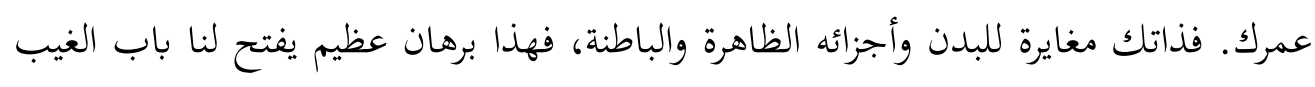
فإن جوهر النفس غائب عن الحس والأوهام(31).

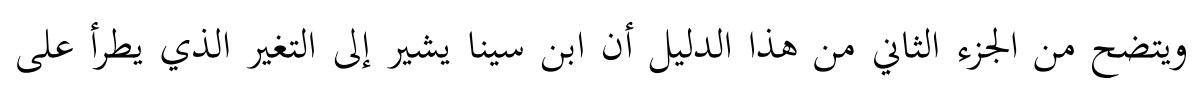

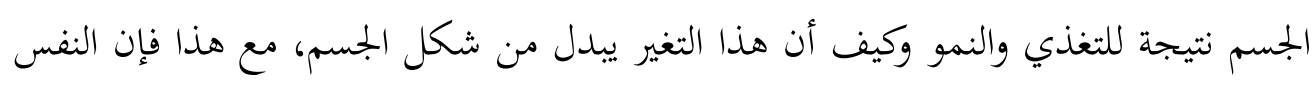


التي تدبر هذا الجمسم تبقى ثابتة لا تتبدل أنانيتها وهذا يعني في نظره أن النفس غير الجسم وأها موجودة.

4- برهان وحدة النفس: لما كانت النفس محلاً للمعقولات، وكانت المعقولات غير جسيمة بحيث لا تنقسم كالأجسام، فلا بد من أن يكون محلها على شاكلتها أي جوهر غير جسمي وغير منقسم، وإذن فالنفس جوهر عقلي غير منقسم. وكذلك فإنه على الرغم من أن للنفس وظائف مختلفة وقوى شهوانية وغضبية ومدركة

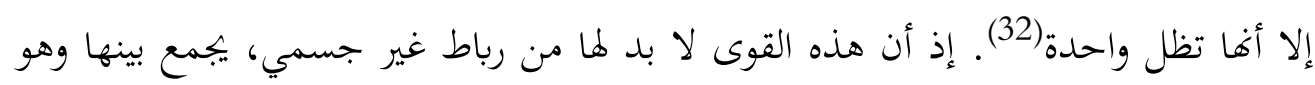
النفس. ففي الإنسان إذن يوجد رباط مجمع لسائر الإدراكات والأفعال، وحينما يشير الإنسان

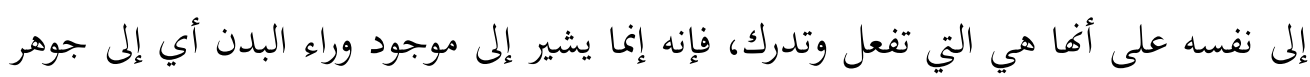

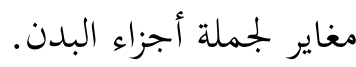

5- برهان الإنسان المعلق في الهواء أو برهان الرجل الطائر: مضمون هذا الدليل أن الإنسان إذا غفل عن أعضاء جسمه فإنه لن يغفل عن ذاته أبدًا.

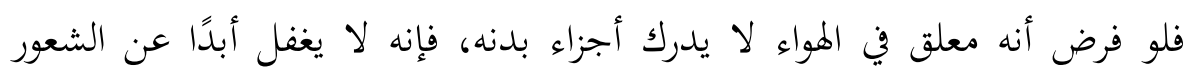

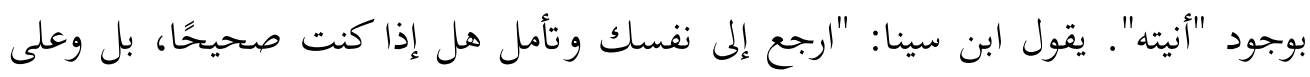

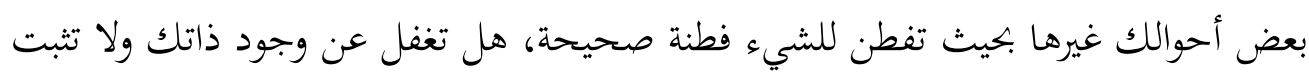

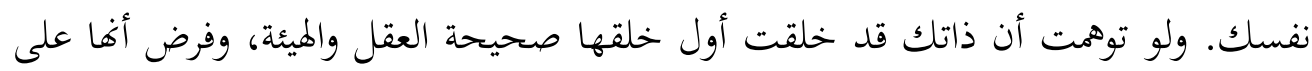

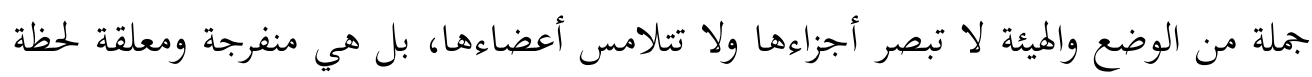
ما في هواء مطلق، وجدها قد غفلت عن كل شيء إلاعن ثبوت أنيتها"(33).

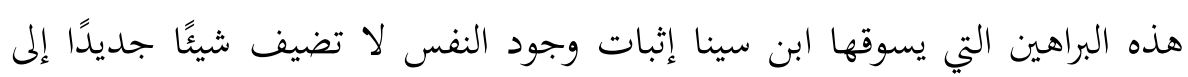

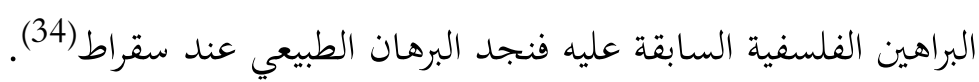

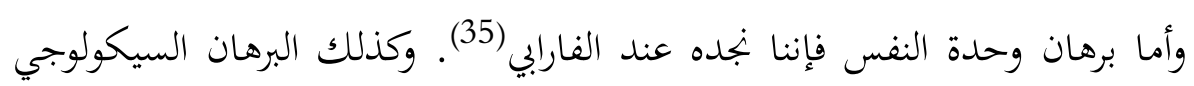
وبرهان الاستمرار فإننا نجدهما لدى أرسطو. ويبقى برهان الرجل الطائر وهو يبدو في صياغة جديدة أما مضمونه فهو مشتق من البراهين السابقة. 
3- النفس وتعددها:

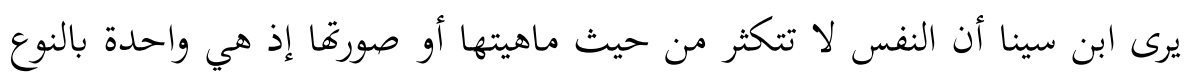

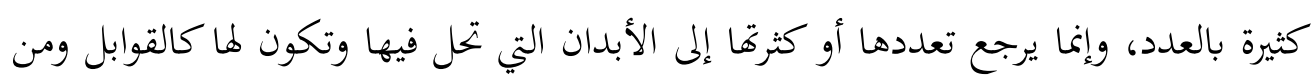

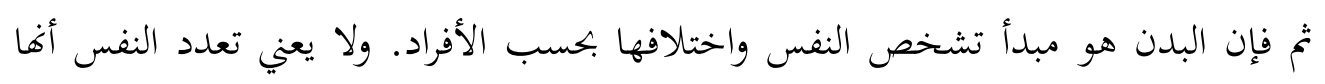

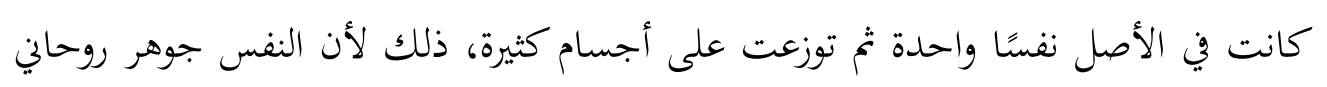

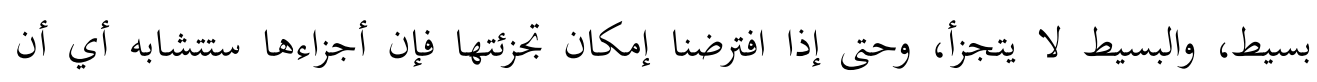

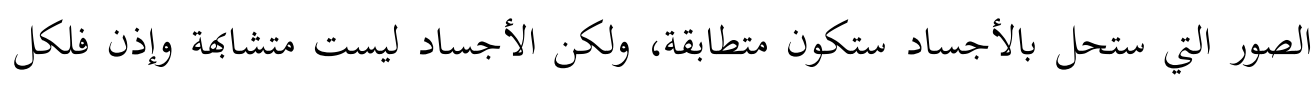

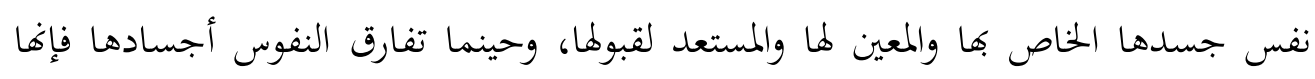

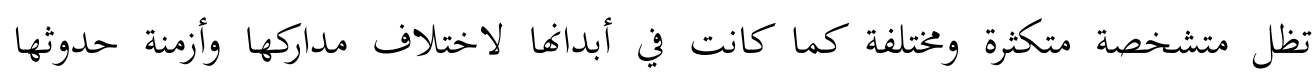
واختلاف هيئاةًا التي غلبت عليها بحكم اتصاها بهذه الأبدان المعينة لها.

\section{4- بقاء النفس أو خلودها عند ابن سينا}

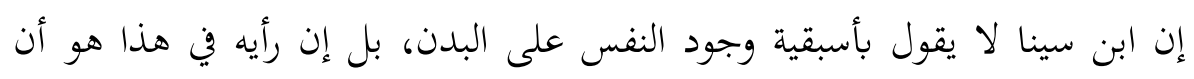

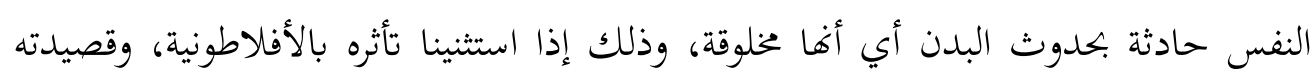

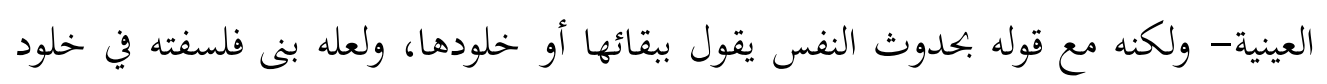

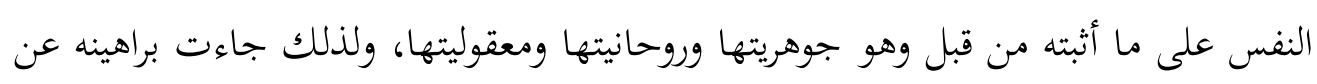

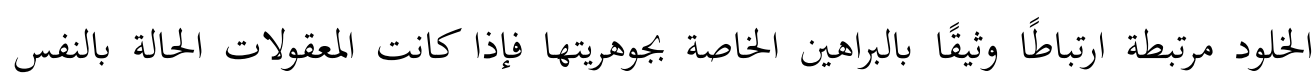

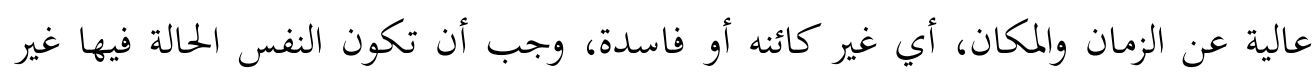
كائنه وغير فاسدة. ويقول - أيضًا- : (إن خلود النفس نتيجة مباشرة لروحانيتها، وبما أن النفس العاقلة

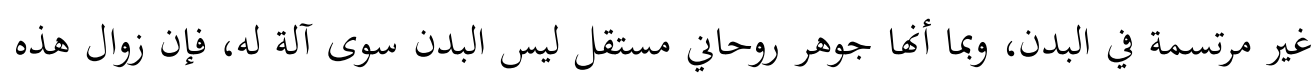

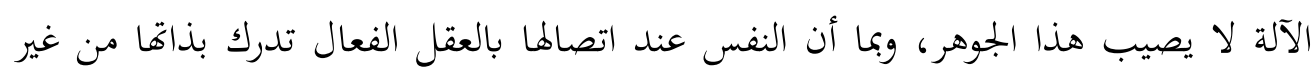

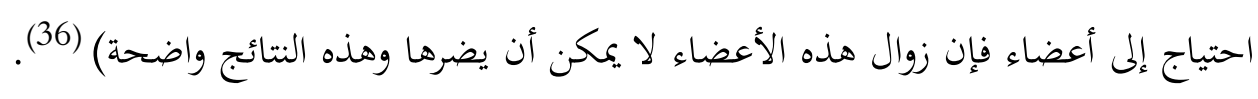




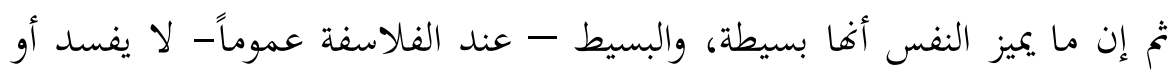

ينحل، أما البدن فلأنه مركب فإنه يعتريه الفساد والانحلال. أما النفس فإها تبقى وتخلد (ربما أن النفس جوهر بسيط فإنها لا تستطيع أن بحمع في نفسها فعل الوجود وقوة الفساد. لأن ابن سينا يرى تضاد هذين الشرطين وعدم إمكان التوفيق بينهما ببساطة الجوهر ولا يمكن

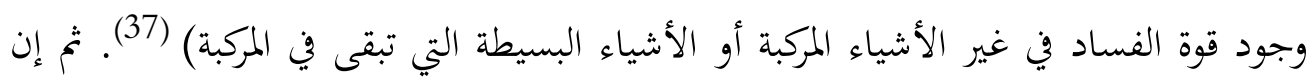
ابن سينا يرى أن النفس مصدر الحياة، وأن إمكانية الفساد منعدمة لديها، فليس بهاء شيء ماء ماء بالقوة من هذه الجهة وعلى ذلك فإها خالدة. يقول ابن سينا: (.. ومحال أن يكون من جهة

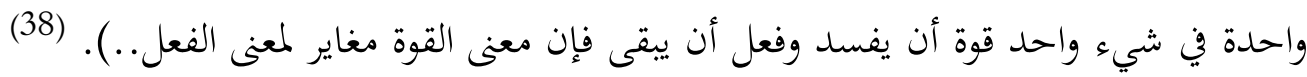

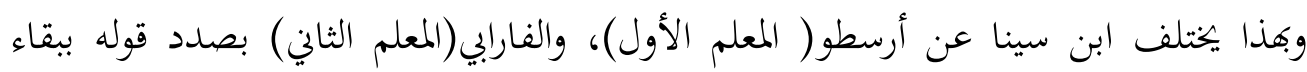

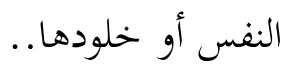

فأرسطو يرى أن العقل الفعال هو وحده الذي يخلد أما باقي النفس الناطقة فإها تفنى بفناء الجسد، وكذلك الفارابي فإنه يقصر الخلود على العقل المستفاد بعد أن جعل العقل

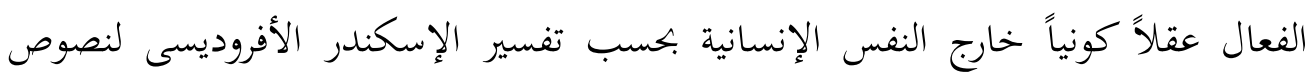

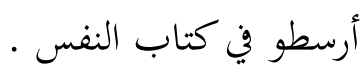

أما ابن سينا فإنه يتمسك بوحدة النفس الناطقة وبساطتها لا يميز فن جزئها الناطق

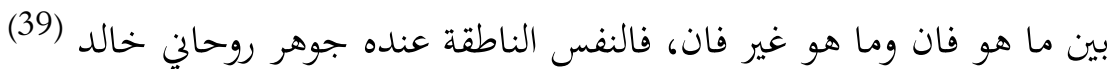
ويذكر الإمام الرازي دليلهم على بقاء النفس فيقول ( قالوا النفس باقية بعد فناء

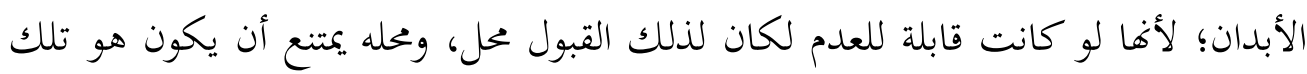
النفس؛ لأن القابل واجب البقاء عند وجود المقبول وجوهر النفس لا يبقى بعد فسادها، فوجب أن يكون محل ذلك الإمكان جوهراً آخر فتكون النفس مركبة من الهيولى والصورة. . . الخ

و يفهم من هذا الدليل: أن النفس يستحيل عليها العدم؛ لأن عدمها لو كان ممكناً

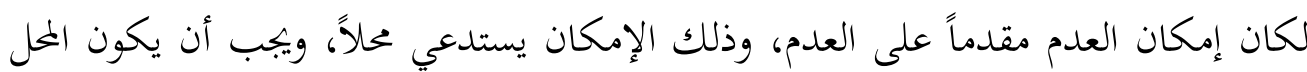

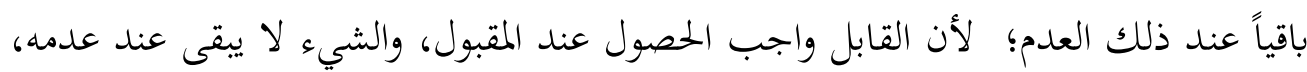




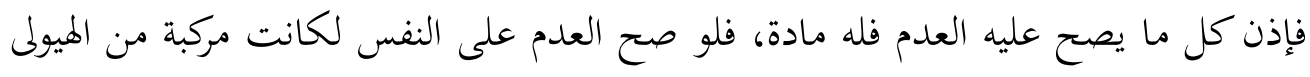

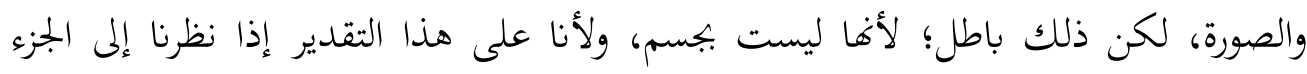

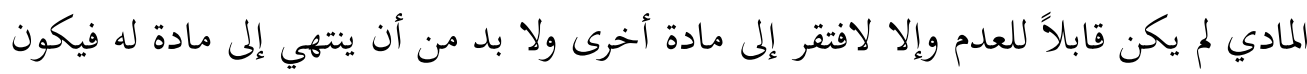

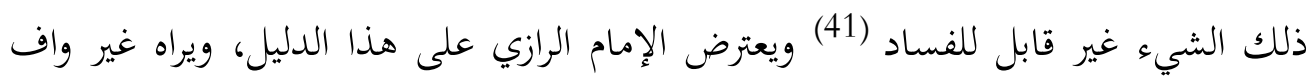

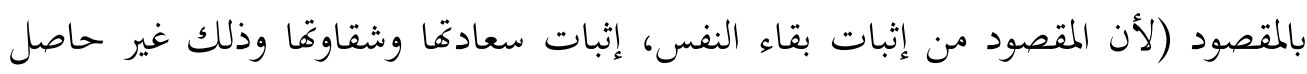

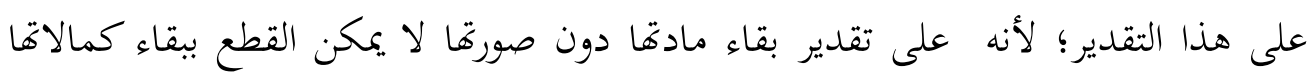

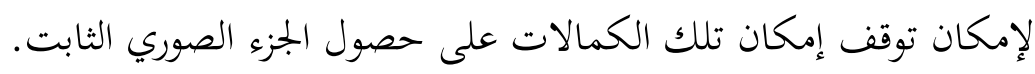

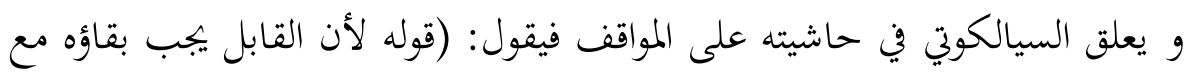

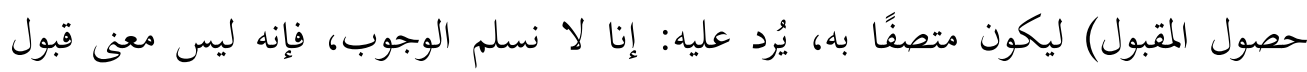

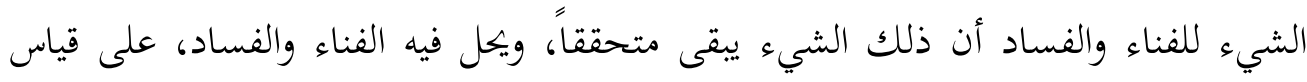

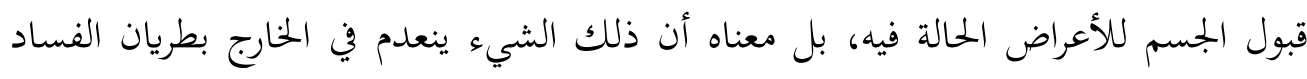

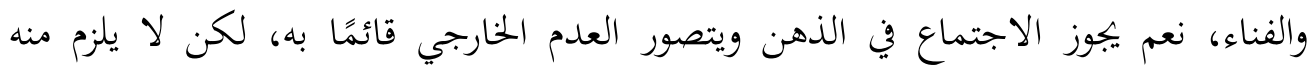

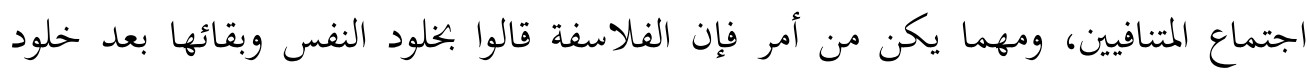

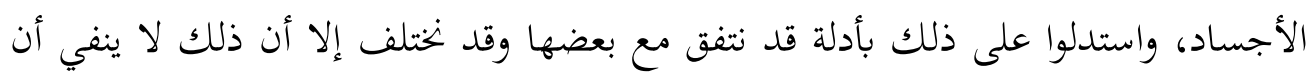

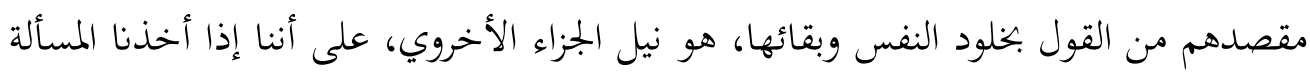

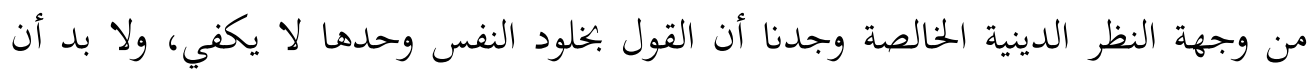

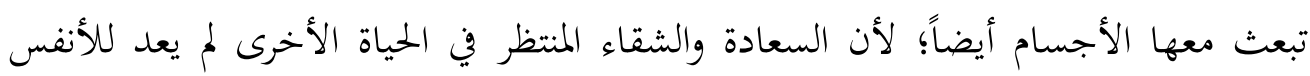

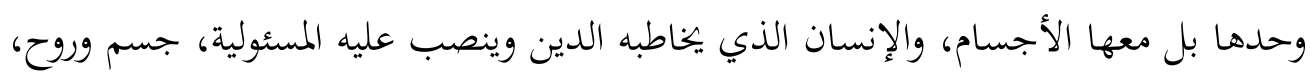

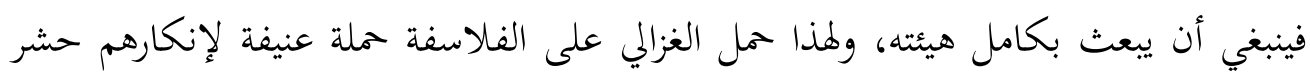

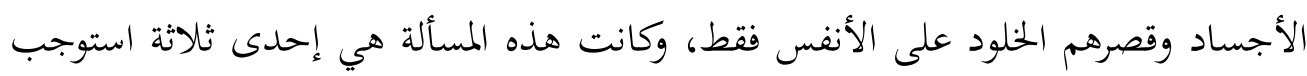

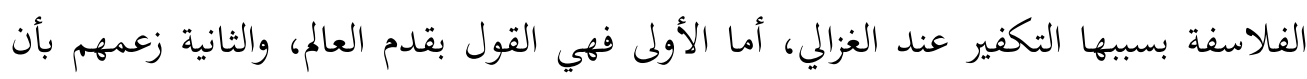
الله لا يعلم الجزئيات، والثالثة إنكارهم حشر الأجساد (42).

5- 5 بلان التناسخ: 
يرفض ابن سينا دعوى القائلين بالتناسخ فهو يرى أنه لما كانت علاقة النفس بالجسد

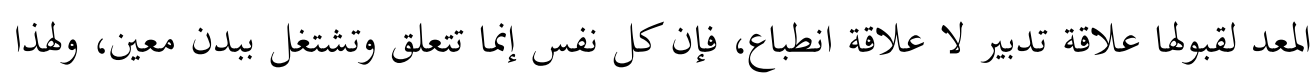
فإن وجود نفس ثانية إلى جوار النفس الحالة في بدن الحيوان إنما يعني وجود نفس معطلة قاصرة عن التدبير، لأن الحيوان إنما يستشعر بنفس واحدة هي التي تدبره وتشتغل بأمره. أما

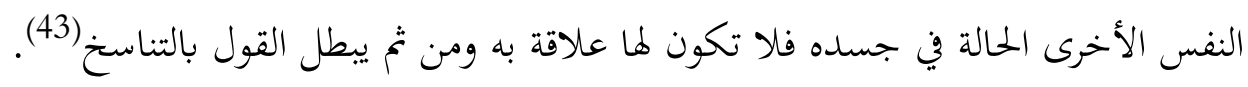
6- قوى النفس وأفعالما: تبين لنا من برهان وحدة النفس عند ابن سينا أن النفس واحدة رغم وجود قوى

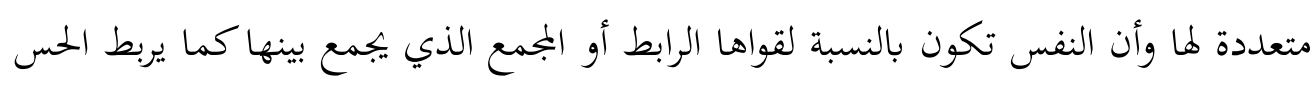

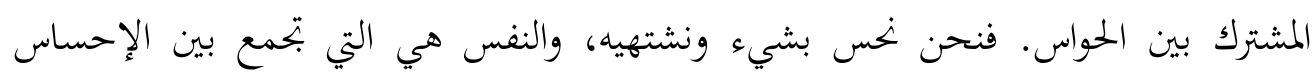

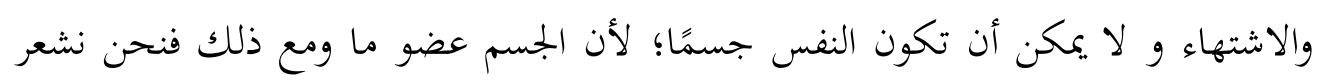
بذواتنا كاملة دون انتقاص. و يرتب ابن سينا للنفس قوى مختلفة بحسب مراتب الحياة الثلاث: النباتية والحيوانية والإنسانية كما فعل أرسطو وكذلك الفارابي بعده.

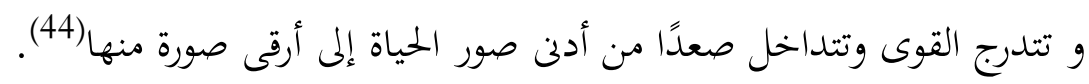
فللنفس النباتية قوى ثلاث: الغاذية، والمنمية، والمولدة(45). وللنفس الحيوانية (بالإضافة إلى قوى النفس النباتية) قوتان: محركة ومدركة. أ) و الخركة على قسمين: 1- محركة على أها باعثة - وهي القوة الشوقية ولها شعبتان: قوة شهوانية وأخرى غضبية. 2- و و مركة على أها فاعلة ب) أما المدركة فهي أيضًا على قسمين: 1- مدركة من خارج، وهي الحواس الخمس الظاهرة: البصر والسمع والشم والذوق واللمس. 
2- ومدركة من داخل، هي الحواس الباطنة: الحس المشترك (فنطاسيا) الخيال والمصور والمتخيلة (وتسمى المفكرة عند الإنسان)، والوهمية والحافظة الذاكرة. وللنفس الناطقة قوتان: (بالإضافة إلى قوى النفس النباتية والحيوانية) قوة عملية، وقوة نظرية، أو قوة عاملة وقوة علمة ولمة.

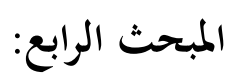

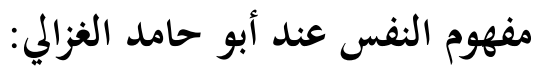

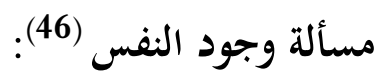

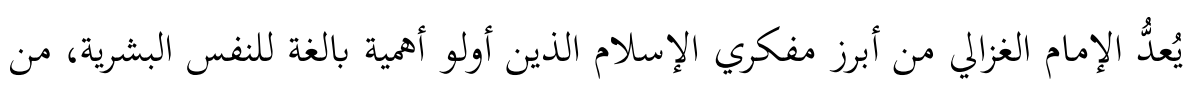

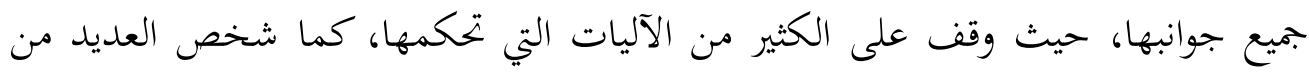

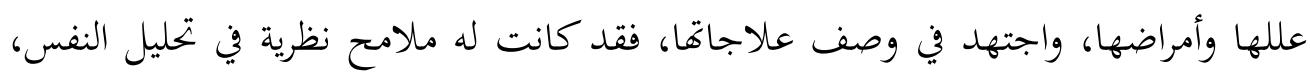
تستمد أصولها من الإسلام.

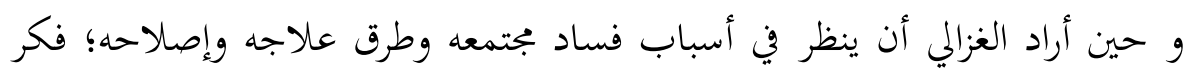

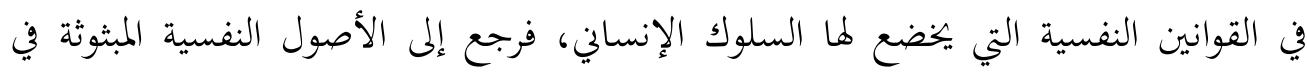

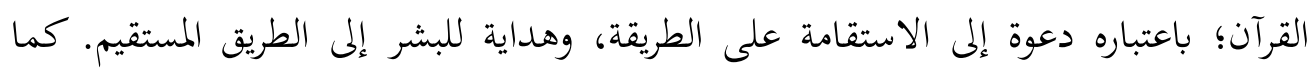

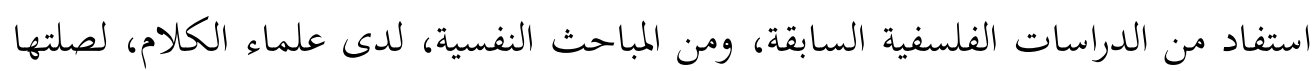

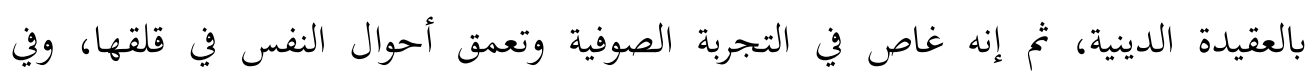
مواجدها ومقاماتها(47).

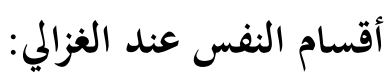

النفس الشهوانية: سيطرة الأهواء، والغرائز، والشهوات على العقل.

• النفس اللوامة: وهي النفس المتوسطة بين صراع الأضداد، الشهوة والعقل.

النفس العاقلة: وهي المطمئنة بحكم العقل، وقمع الشهوات والتحكم فيها.

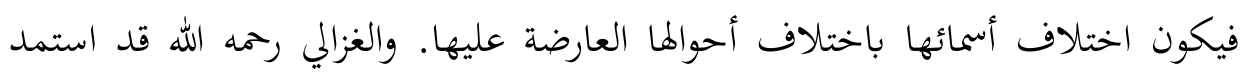

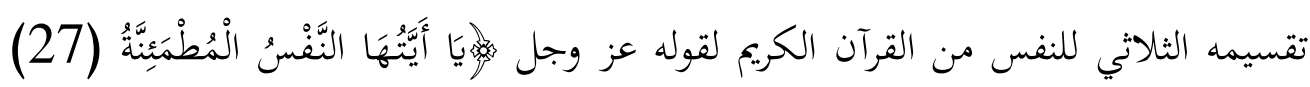

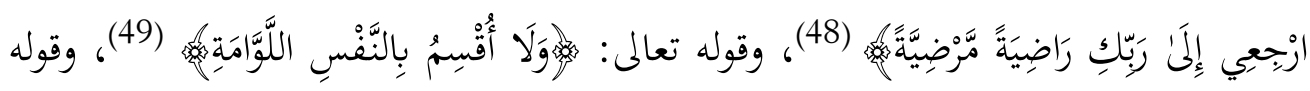




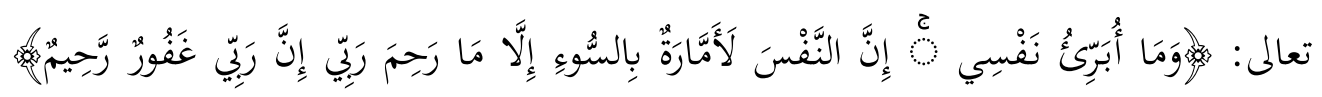

أما النفس الإنسانية فهي تشبه العالم الأعلى وهي ذات طبيعة إلهية وإلا لما استطاعت

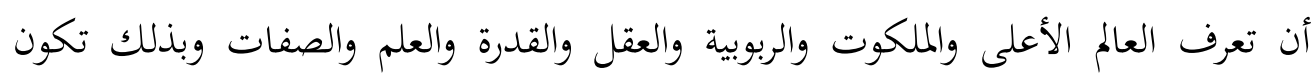

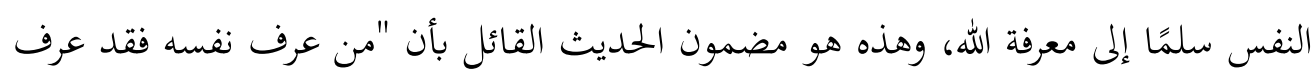

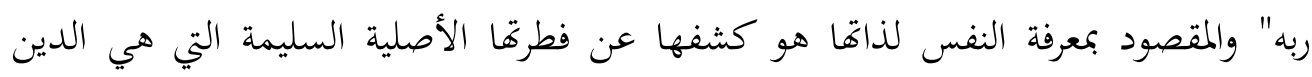

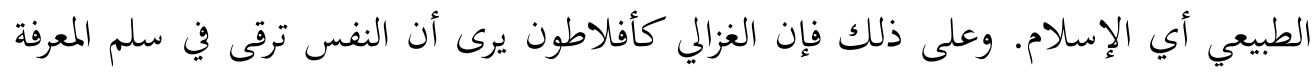

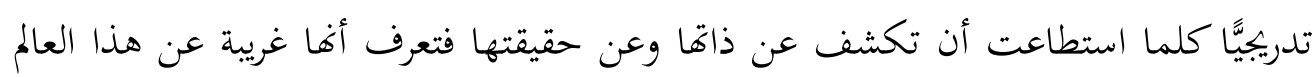

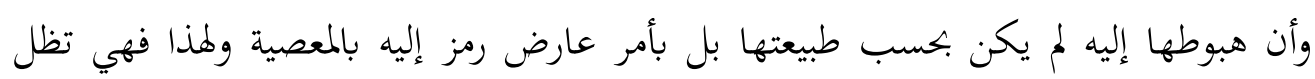
دائمة الشوق و الحنين للعودة إلى جوار الله.

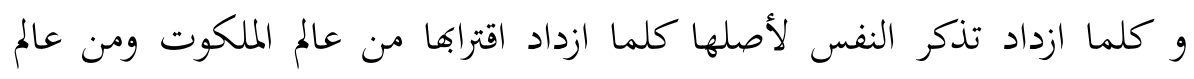

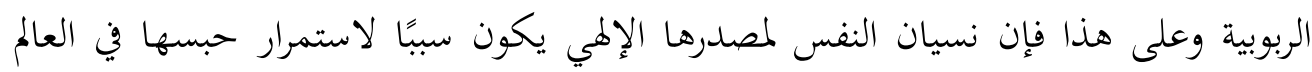

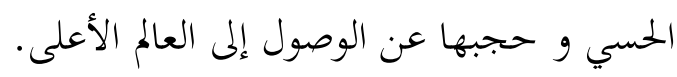

\section{(أ) النفس: وجودها وطبيعتها، وعلاقتها بالبدن:}

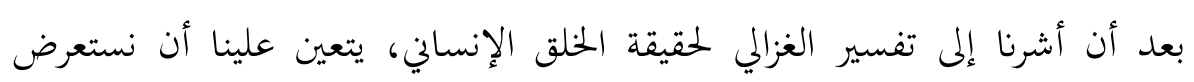
مجمل آرائه حول النفس ووجودها وطبيعتها وقواها ومصيرها وعلاقتها بالبدن. و نصوص الغزالي لا تشير إلى موقف واحد ثابت بصدد النفس، بل إننا نجد لديه

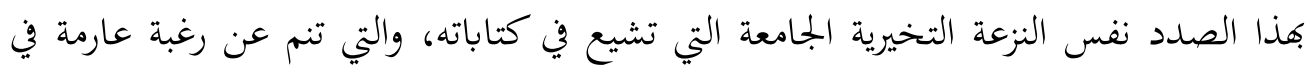

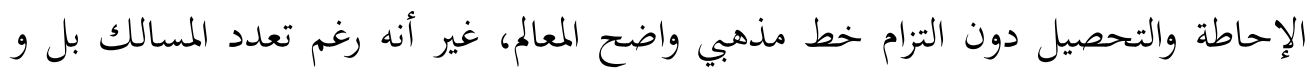

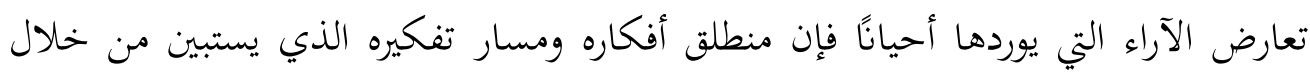

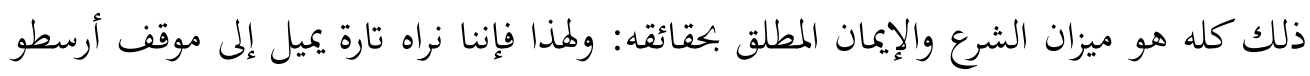

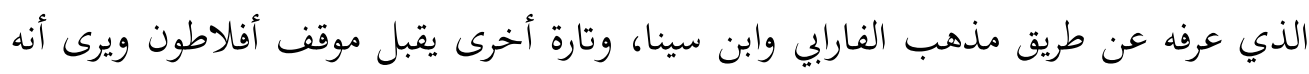


متفق مع العقيدة و أيضًا نجده ينتقد آراء الفلاسفة حول النفس في التهافت) ثم يقبل آراءهم

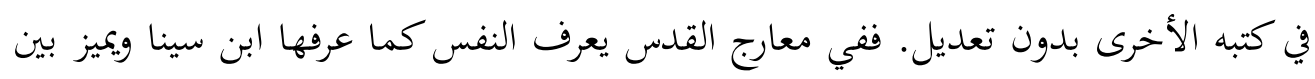
نفس نباتية ونفس حيوانية وثالثة إنسانية.

و يرى الغزالي أن النفس كالبدن لا تخلق كاملة، بل تكمل بالنساية بالتربية والتهذيب، وأن

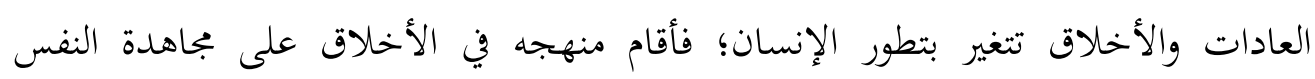

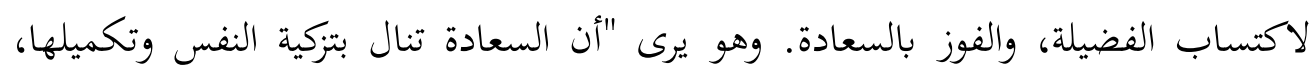
وأن تكميلها باكتساب الفضائل كلها"(51).

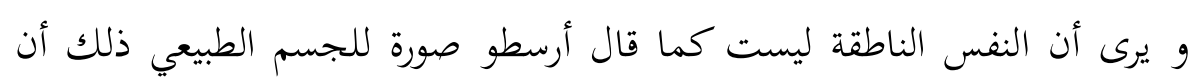

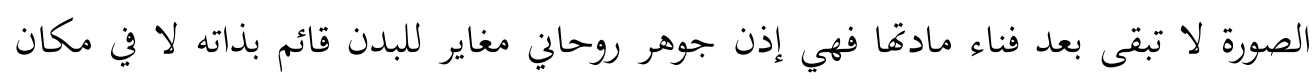

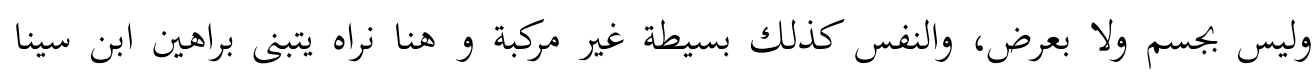

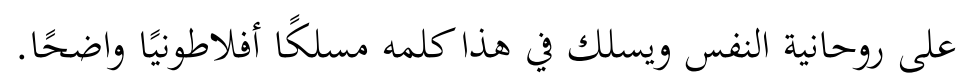

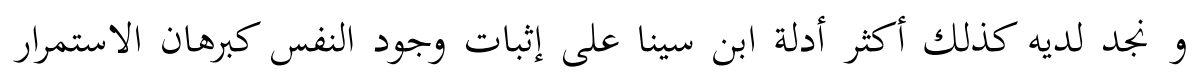

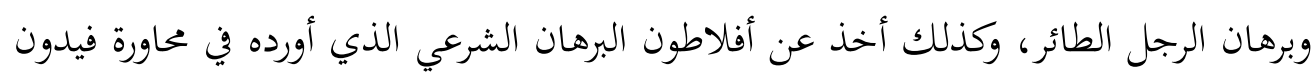

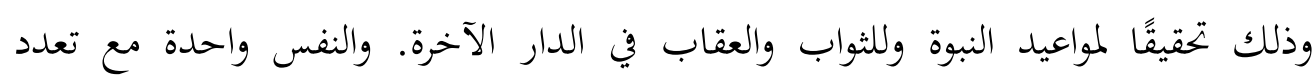

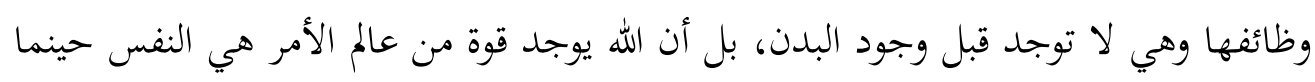

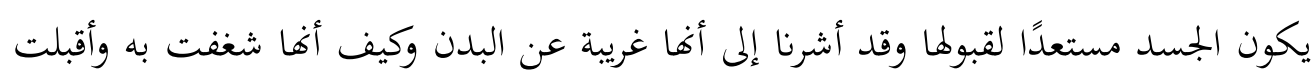
عليه وأصبحت مدبرة له وأضحى هو آلتها. (ب) خلود النفس ومصيرها:

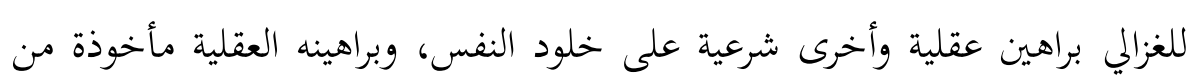
ابن سينا وعلى ذلك فهو ينتقد في (التهافت) الفلاسفة القائلين بخلود النفس واستحالة فناء

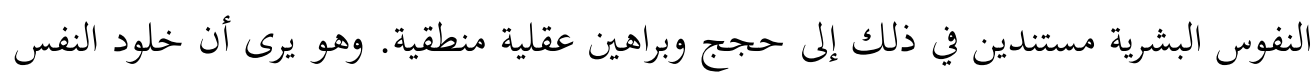

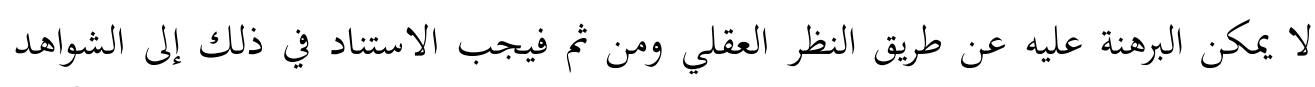

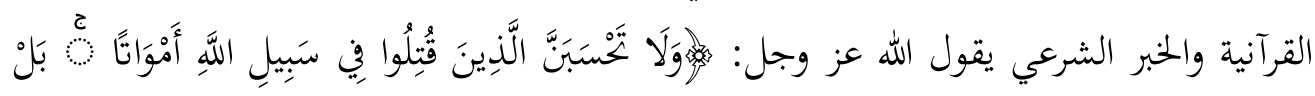

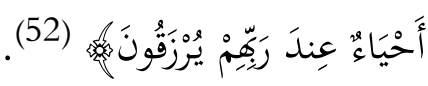


2- أما من حيث مصير النفس بعد الموت فيرى الغزالي أنه هناك ثلاث طوائف من الناس: الطائفة الأولى من النفوس فهي التي شغلتها هيئاتها الردية ونوازعها البدنية عن طلب المعرفة وتطهير القلب من أدران الرذيلة، وهؤلاء هم مرتكبو الكبائر الذين يرى أهل السنة - والغزالي تهني

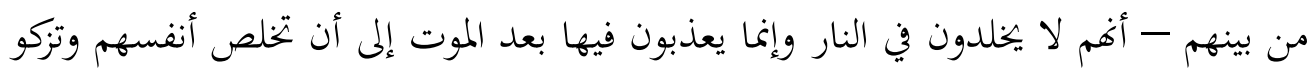

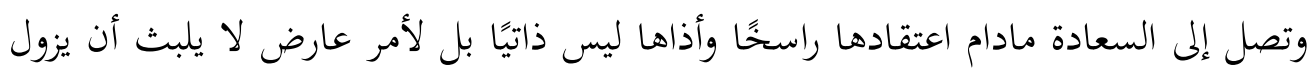

بالبقاء الموقوت في النار. (53)

أما الطائفة الثانية من النفوس فهي نفوس البله تلك التي لم تكتسب الشوق ولم تحن إلى المعارف، فإها إذا فارقت الأبدان وهي غير مكتسبة للرذائل، فإِها تصير إلى سعة رحمة الله وتخلد إلى الراحة في الدار الآخرة. و أخيرًا نجد الطائفة الثالثة من النفوس وهي نفوس اشتد تعلقها بالرذيلة فجحدت الحق وتعصبت للآراء الفاسدة ورسخت فيها الهيئات الردية، فتفوقا بالموت آلة إدراك الشوق واقتناص العلوم فتعجز عن الاتصال بالعقل الفعال و تخلد في النار.

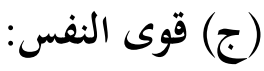

يتابع الغزالي موقف ابن سينا في تفضيله لقوى النفس فيرى أن للنفس النباتية قوى ثلاث هي: الغاذية والمنمية والمولدة، وللنفس الحيوانية - بالإضافة إلى ما سبق من قوى نوعان من القوى: محركة ومدركة، والمخركة إما باعثة على الحركة وإما مباشرة للحركة... الخ. أما المدركة فهي: إما ظاهرة كالحواس الخمس، وإما باطنة كالحس المشترك والخيال والوهم والحافظة والمنصرفة.

ويختلف ترتيب هذه القوى من كتاب إلى آخر عند الغزالي، وهو يكتفي في "معراج السالكين" بذكر ثلاث قوى باطنية هي: الخيالية والوهمية والمفكرة. أما النفس الإنسانية فإن لديها - بالإضافة إلى ما سبق - قوة ناطقة هي العقل، وله قوتان إحداهما عملية وهي مبدأ محرك لبدن الإنسان إلى الصناعات الإنسانية وأما القوة الثانية فهي علمية تدرك حقائق العلوم مجردة عن المادة والصورة. 
والغزالي يتكلم عن معاني العقل كما أوردها الفارابي في رسالة (العقل) دون أن يشير

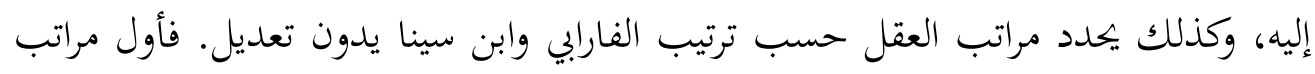

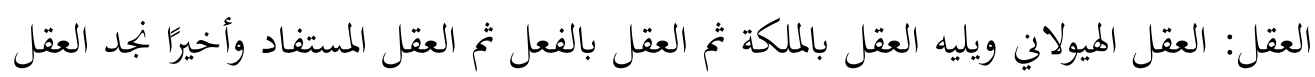
الفعال وهو عقل كوني خارج عن النفس الإنسانية يفيض عليها المعرفة بحسب استعدادها لقبول إشراقه. (54)

الحاتمة:

بعد دراستي لمفهوم النفس عند الفيلسوف الكندي والفارابي وابن سينا والغزالي ومن خلال البحث تبين لي النتائج التي توصلت إليها وهي:

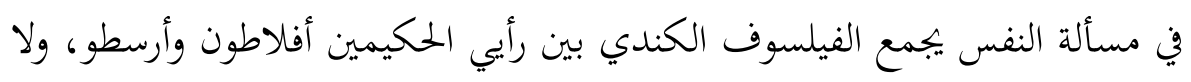

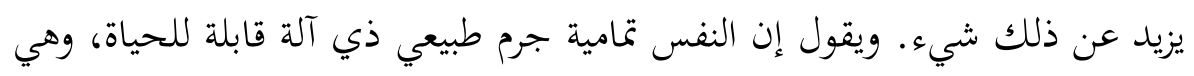

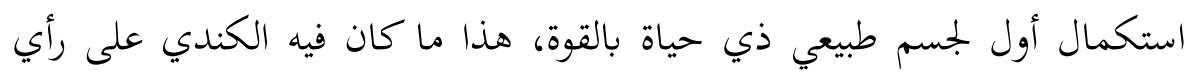

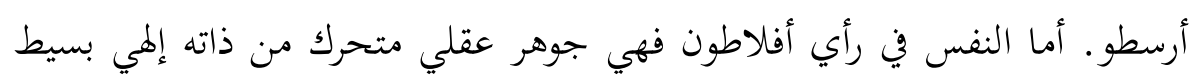

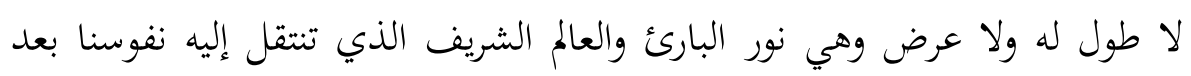


الموت. وهو مقامها الأبدي ومستقرها الدائم. فالنفس عند الكندي خالدة ولكنه لا

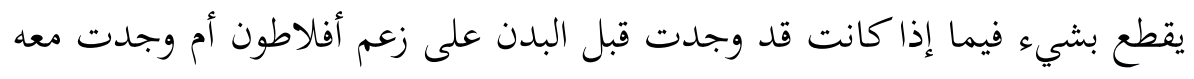

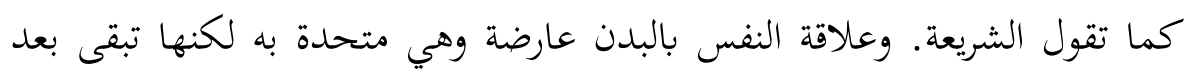
فنائه، وتسير النفس بعد موت البدن إلى المستقر الأعلى.

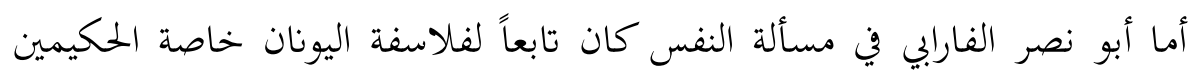

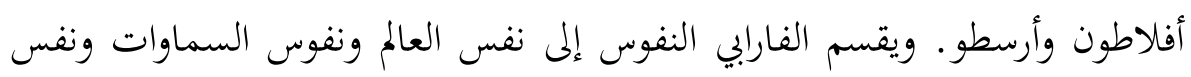

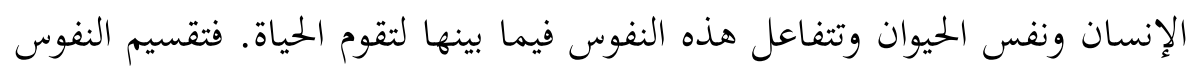
عند الفارابي هو نفس التقسيم الذي نجده عند أرسطو في كتاب النفس.

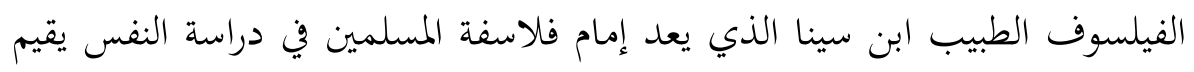

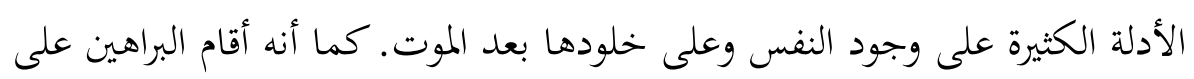
أن الصلة بين الروح والجسد صلة عرضية فلا يؤدي فناء الجسلد إلى فناء الروح.

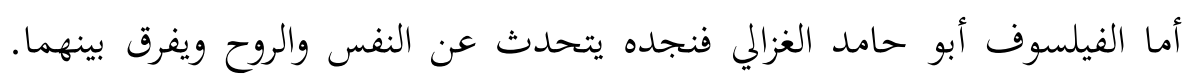

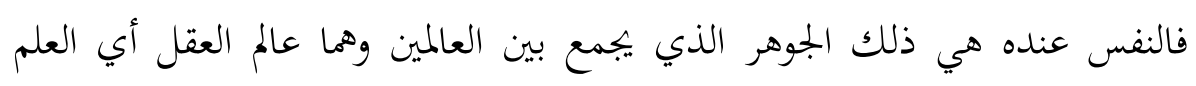

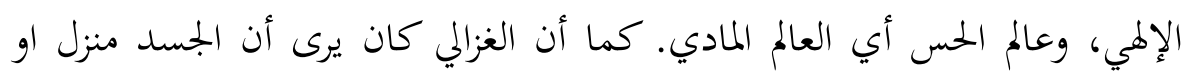

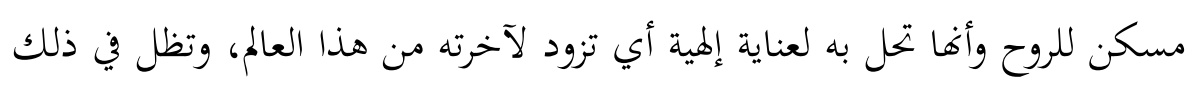

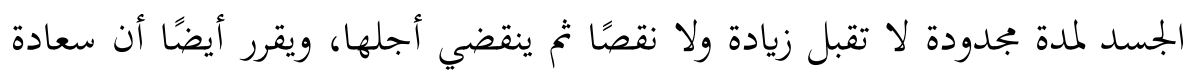

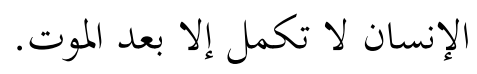

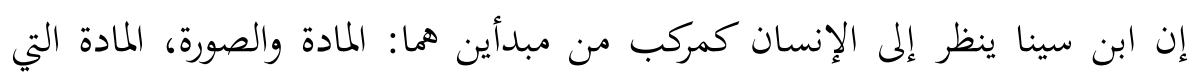

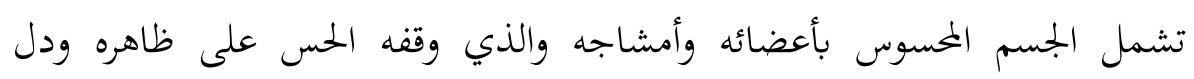

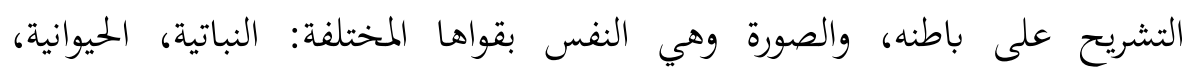

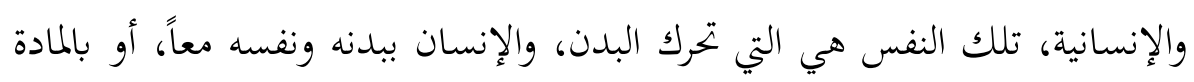
والصورة في نفس الوقت، ولذا اهتم ابن سينا في تربيته بالصبي جسمه وعقله معال معاً.

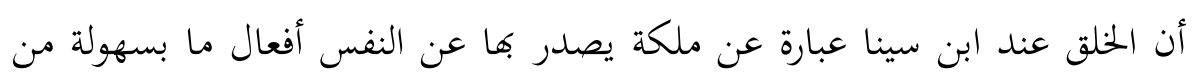

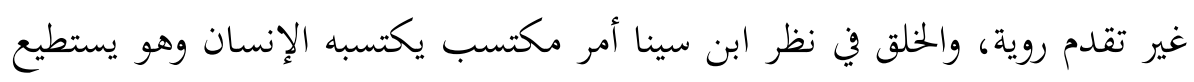


عن طريق المجاهدة أن يغير منه، ووسيلته إلى ذلك إحكام عقله وسيطرته على قوتيه

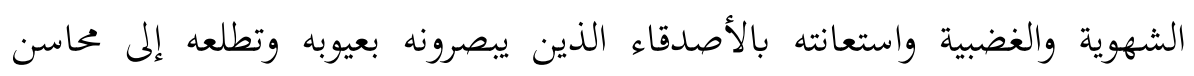
الآخرين وعيوبهم، يستفيد من الولى ويحذر من الثانية.

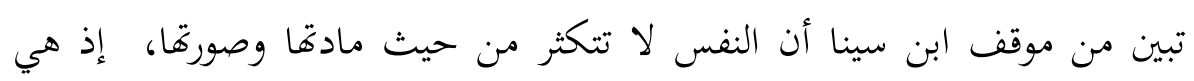

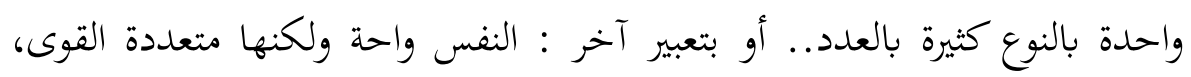

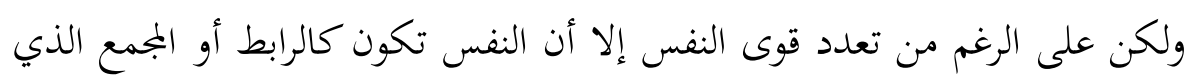

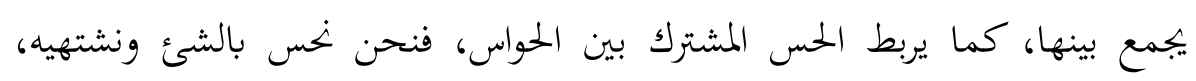
والنفس تربط بين الإحساس والاشتهاء، ويرتب ابن سينا قوى النفس المتعددة بحسب لئب مراتب الحياة الثلاثة: النباتية، الحيوانية، الإنسانية، كما فعل الفارابي من قبل.

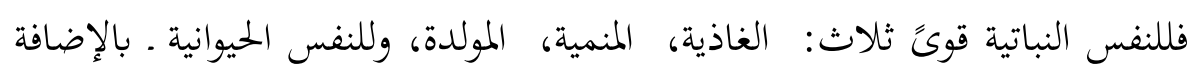

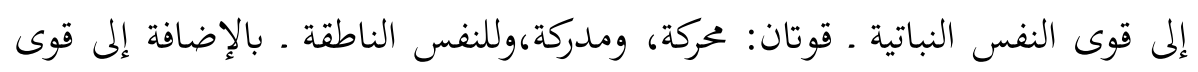
النفس النباتية والحيوانية ـ قوتان: عملية، أو عاملة، نظرية، أوعالمة. يحدد ابن سينا للنفس صفات وأهمها، جوهرية النفس، فهي ليست صورة فقط للبدن

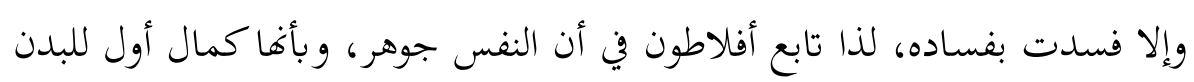
ولكن يجب أن نلحظ هنا أن لم يقصد أن يكون الكمال كعرض بل هو كمالا كالجوهر، وذلك لأن النفس لا تحتاج للبدن كما هو بحاجتها. يثبت الفارابي للّنفس ثلاث قوى إدراكيّة، إثّا قوّة الحسّ، وقوّة التّخيّل، وقوّة التعقّل.

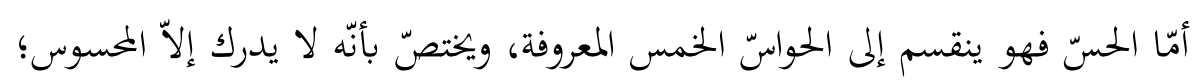
والخيال هو يدرك ما ارتسم من المحسوس بعد ذهابه، لكنّه هذا المرتسم تبقى فيه

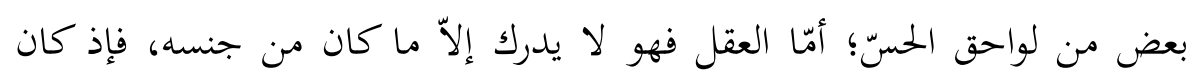

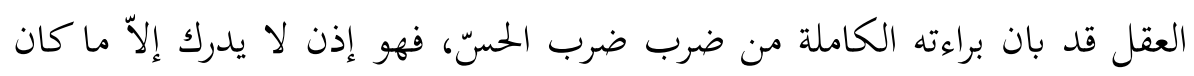
خالصا كلّ الخلوص من شائبات الحسّ وشائبات التّعيّن. جمع الكندي في مسألة النفس بين رأي الحكيمين أفلاطون وأرسطو، فيشير إلى

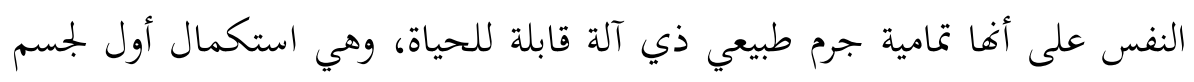


طبيعي ذي حياة بالقوة. هذا ما كان فيه الكندي على رأي أرسطو، أما فيما تبع به أفلاطون، فهي جوهر عقلي متحرك من ذاته، وهي جوهر إلهي بسيط، وهي نور الباري. والعالم الشريف الذي تنتقل إليه نفوسنا بعد الموت هو مقامها الأبدي

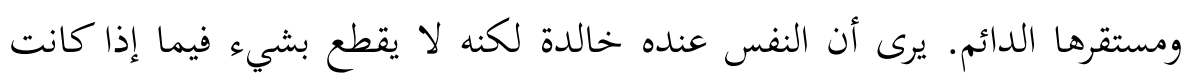
قد وُجدت قبل البدن كما ذكر أفلاطون أم وجدت معه كما يرى أرسطو. كما أنه يرى أن علاقة النفس بالبدن عارضة، فهي لا تفعل إلا بالبدن، كما أهما

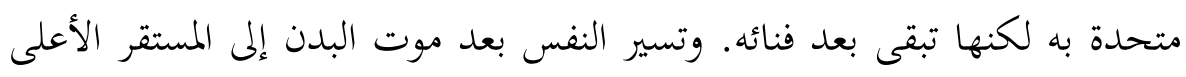
مباشرة .

يقسم الكندي النفس إلى قوى ثلاث هي: القوى الغضبية، والقوى الشهوانية، والقوى العقلية، ويحدد في الجسد آلة يشترك بها الحس والعقل هي الدماغ، وآلتها التي تدرك بها جميع المحسوسات هي أعضاء الحس الخمسة. كما أنه يقسم قوى النفس فيس

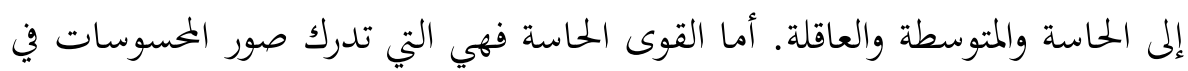
مادتا، وأما القوى المتوسطة فهي القوى المصورة والمتخيلة، وهي التي توجد صور الأشياء مع غيبة حواملها عنها. ومنها القوى الحافظة وهي الذاكرة، ومنها القوى الغضبية وهي التي تدفع الإنسان إلى ارتكاب الأمر العظيم، ومنها الشهوانية الغازية،

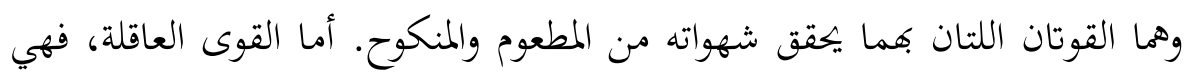
التي تدرك صور المجردات دون مادة، أي القدرة على الفكر المجرد والانتقال من المن العقليات إلى العقليات. هناك نوعان من الأنفس في منظومة الفارابي الفلسفية: الأنفس التي فوق فلك القمر،

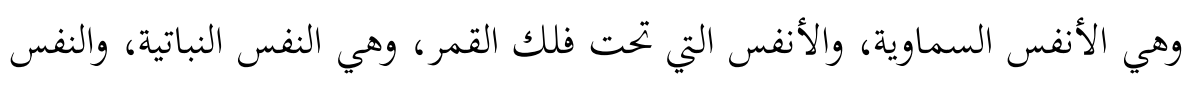
الحيوانية، وهي نوعان: النفس الحيوانية والنفس الناطقة التي يختص بها الإنسان. فرق الفارابي بين هذه الأنفس، فالأنفس السماوية أنفس مختلفة بالنوع عن الأنفس ولنس

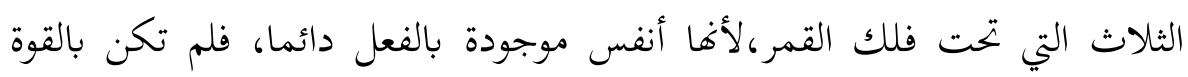


أبدا، وهي موجودات أزلية لأهما تعقل أمور أزلية، وكل نفس من الأنفس السماوية

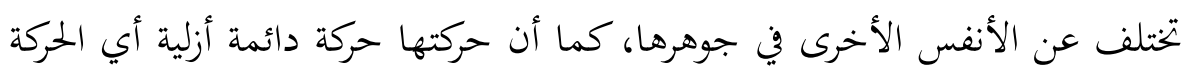

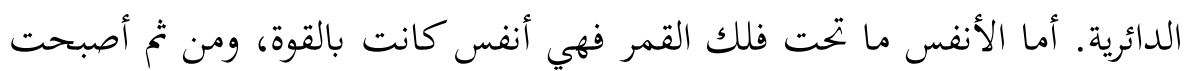
بالفعل، أي أها احتاجت لمن يخرجها من العدم للوجود، فهي ليست أزلية، وبالتالي إدراكها سيكون للأمور المتغيرة رغم أن النفس الناطقة قد تصل لمرتبة العقل الفعال بمساعدته فتدرك الأزليات. وتشترك الأنفس بأها يعتريها شيء من النقص، يعتري كل الموجودات إلا الأول،

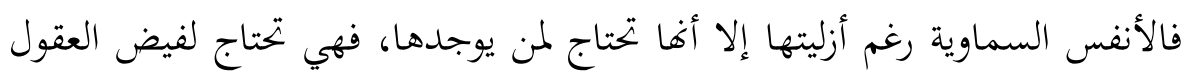
السماوية لكي توجد وهو فيض متصل إلى الأول. والأنفس الحيوانية، والنباتية تحتاج العقل الفعال لكي تترقى وجوديا ولكي تكون. للنفس الإنسانية عند الفارابي تصور أفلاطوني بمنظور أرسطي، فهو يستعير من

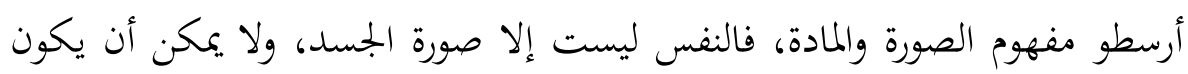

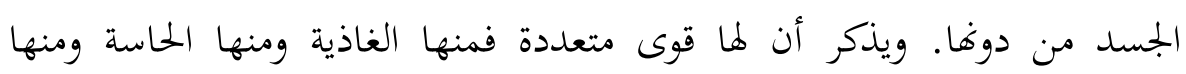
الناطقة والنزوعية. أما النزوعية فهي قوة الشوق أو النفور التي تكون للحاسة والغاذية

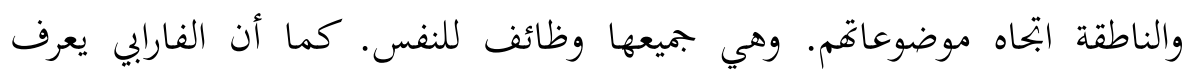
النفس بأها "استكمال أول لجسم طبيعي آلي ذي حياة بالقوة، وهو هنا يقدم تعريفا أرسطيا عن النفس، ولكنه يرى أيضا أن النفس وجدت قبل النب البدن، وتبقى بعد فنائه،

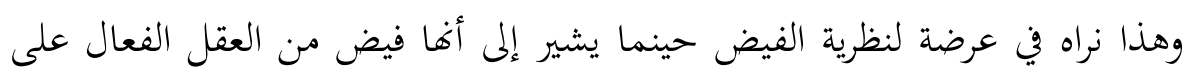
البدن المستعد لقبوها. 


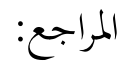

إبراهيم مدكور: في الفلسفة الإسلامية منهج وتطبيقه، مكتبة الدراسات الفلسفية، د.ت.

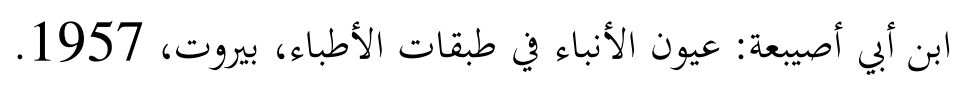
ابن النديم: الفهرست، المكتبة التجارية، القاهرة، د.ت.

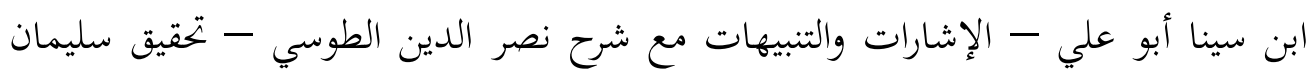

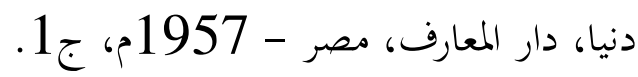

$$
\begin{aligned}
& \text { ابن سينا: أبو علي: الشفاء -- الطبيعيات - النفس - تحقيق الأب جورج الـ قنواتي - سعيد } \\
& \text { زايد - القاهرة - } 1975 .
\end{aligned}
$$




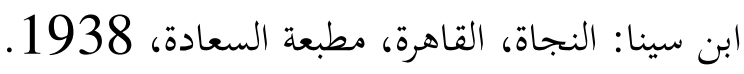

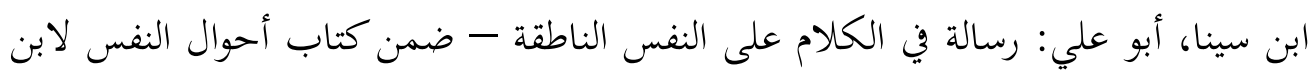

$$
\text { سينا، دار إحياء الكتب العربية - القاهرة. }
$$

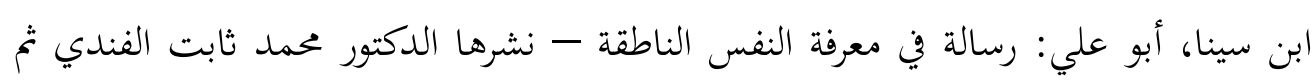

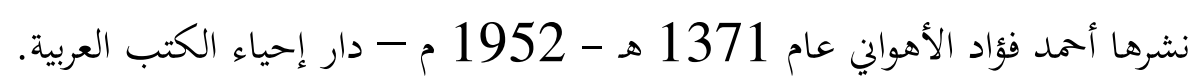

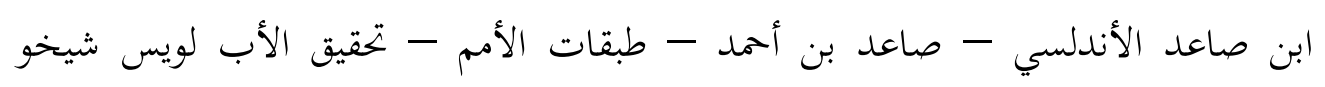

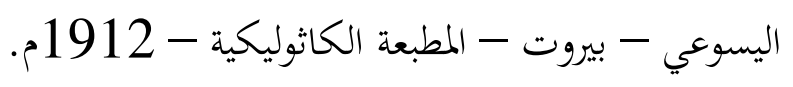

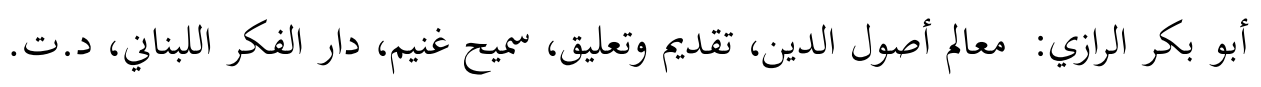

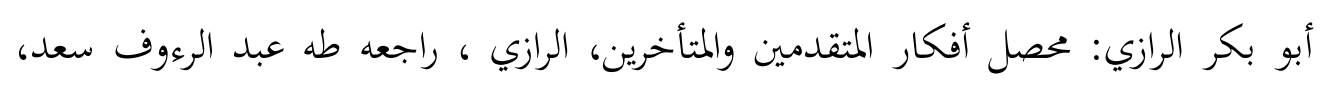

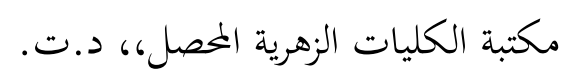

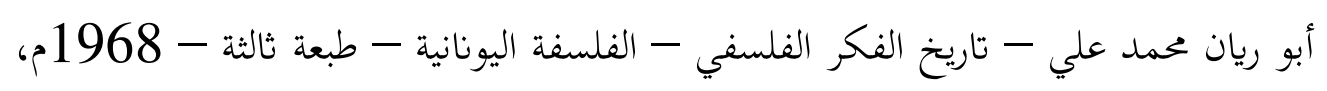

$$
\text { دار المعرفة - الإسكندرية. }
$$

الأهواني، أحمد فؤاد: الكندي فيلسوف العرب - وزارة الثقافة والإرشاد القومي، القاهرة،

\section{4م.}

البارون كارادى فو: ابن سينا، ترجمة عادل زعيتر، دار إحياء الكتب العربية سنه 1959م القاهرة.

بدير عون: الفلسفة الإسلامية في المشرق، دار الثقافة للنشر، د.ت.

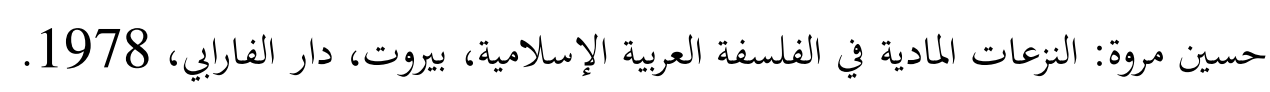

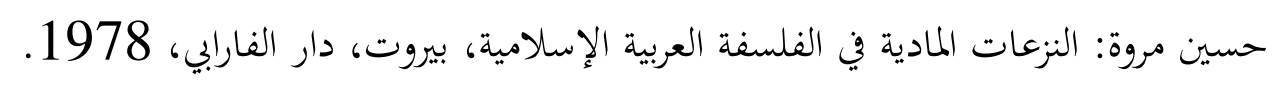

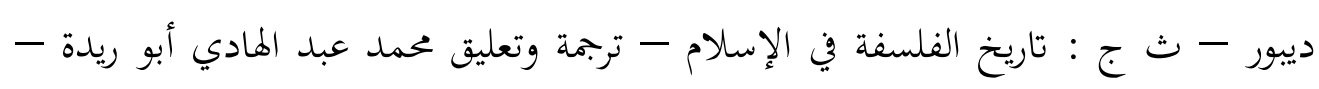

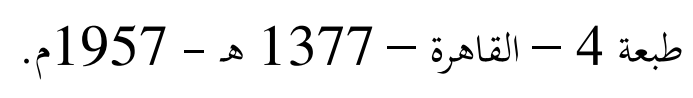

زكي مبارك: الأخلاق عند الغزالي، القاهرة، مطبعة الشعب، 1970. 
عبد الكريم العثمان: الدراسات النفسية عند العرب والغزالي بوجه خاص، القاهرة مكتبة وهبة، .1962

الغزالي، أبو حامد محمد بن محمد بن أحمد: معراج السالكين، القاهرة، مطبعة السعادة، .1924

الغزالي، أبو حامد: ميزان العمل، كتب هوامشه: أحمد شمس الدين، بيروت، دار الكتب العلمية، 1989.

الفارابي، أبو نصر: آراء أهل المدينة الفاضلة، - تحقيق: البير نصر نادر، ط 2، المطبعة

الكاثوليكية، بيروت 1968م.

الفارابي، أبو نصر محمد بن محمد: رسالة في العقل للفارابي، تحقيق: موريس بويج، بيروت،

المطبعة الكاثوليكية، 1938 لمبن

الكندي، يعقوب بن يوسف: رسائل الكندي الفلسفية (رسالة في النفس)، تحقيق عبد الهادي

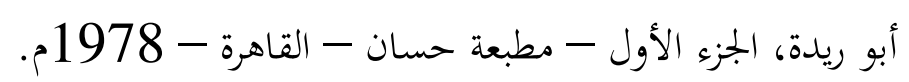

لذة عياد العتبيي: الأسس الفلسفية للتربية عند الغزالي، مجلة التربية، كلية التربية، جامعة الأزهر،

$$
\text { د.ت. }
$$

محمد علي أبو ريان: تاريخ الفكر الفلسفي في الإسلام (النفس عند أرسطو)، الجزء الثاني، دار

$$
\text { إحياء الكتب العربية، } 1945 .
$$

محمد كاظم الطريحي: الكندي فيلسوف العرب الأول (حياته وسيرته وآراؤه وفلسفة رسالته في دفع الأحزان)، بغداد، مكتبة المعارف، 1962. محمود قاسم: في النفس والعقل لفلاسفة الإغريق والإسلام، القاهرة، مكتبة الأنجلو المصرية، .1969 ميلود حميدات: تحليل النفس وتشخيص أحوالها ووصف أمراضها عند الغزالي، دار المنظومة 
نجاتي، محمد عثمان: الإدراك الحسي عند ابن سينا - القاهرة - دار المعارف، الطبعة الثانية 1961-

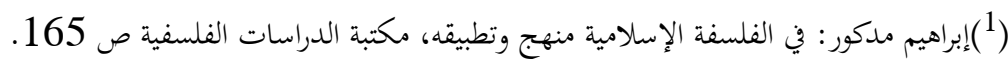

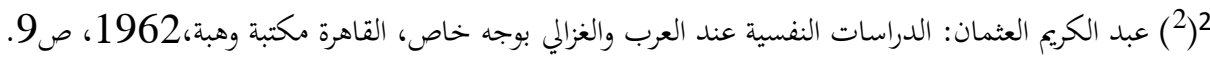

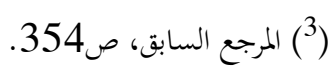


(4) للذة عياد العتيبي: الأسس الفلسفية للتربية عند الغزالي، مجلة التربية، كلية التربية، جامعة الأزهر، د.ت، ص657، .658

انظر ابن النديم: الفهرست، المكتبة التجارية، القاهرة، د.ت، ص 255. ابن أبي أصيبعة: عيون الأنباء في طبقات

الأطباء، بيروت، 1957، ص123، ابن صاعد الأندلسي - صاعد بن أحمد - طبقات الأهم - تمقيق الأب لويس شيخو اليسوعي - بيروت - المطبعة الكاثوليكية - 1912م، ص59، أبو ريان محمد علي - تاريخ الفكر الفلسفي الفلسفة اليونانية - طبعة ثالثة - 1968م، دار المعرفة - الإسكندرية، ص219.

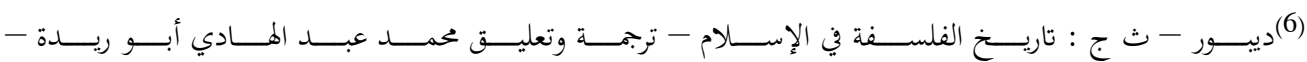

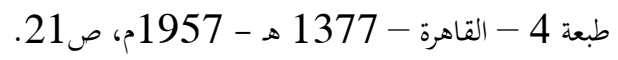

(7) محمد علي أبو ريان: تاريخ الفكر الفلسفي في الإسلام، مرجع سابق، ص 230.

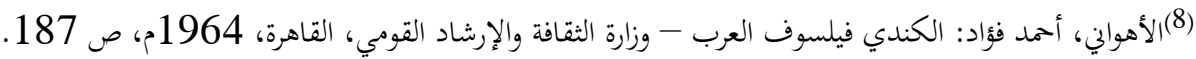
(9) الكندي، يعقوب بن يوسف: رسائل الكندي الفلسفية (رسالة في النفس)، تحقيق عبد الهادي أبو ريدة، الجزء الأول مطبعة حسان - القاهرة - 1978م، ، ومحمد علي أبو ريان: تاريخ الفكر الفلسفي في الإسلام، مرجع سابق، ص 230. (10)الكندي، يعقوب بن يوسف: رسائل الكندي الفلسفية (رسالة في النفس)، تحقيق عبد الهادي أبو ريدة، مرجع سابق.

$$
\text { (11) المرجع السابق. }
$$

(12) حسين مروة: النزعات المادية في الفلسفة العربية الإسلامية، بيروت، دار الفارابي، 1978، صرانع 110.

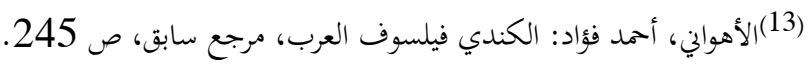

(14) محمد كاظم الطريحي: الكندي فيلسوف العرب الأول (حياته وسيرته وآراؤه وفلسفة رسالته في دفع الأحزان)، بغداد،

$$
\text { مكتبة المعارف، 1962، صكاطم المريكي: }
$$

(15) الأهواني، أحمد فؤاد: الكندي فيلسوف العرب، مرجع سابق، ص، 259.

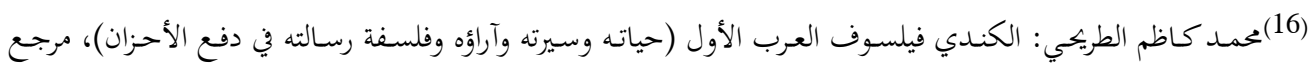
سابق، ص101)

(17) الأهواني، أحمد فؤاد: الكندي فيلسوف العرب، مرجع سابق، ص 243

$$
\begin{aligned}
& \text { (18) المرجع السابق، ص245 - } 246 . \\
& \text { (19 ) نفسه ص249. }
\end{aligned}
$$

20 محمد علي أبو ريان: تاريخ الفكر الفلسفي في الإسلام (النفس عند أرسطو)، الجزء الثاني، دار إحياء الكتب العربية، 
21 الفارابي، أبو نصر: آراء أهل المدينة الفاضلة ،-تحقيق: البير نصر نادر، ط 2، المطبعة الكاثوليكية، بيروت 1968م، ص 101. 22 الفارابي، أبو نصر: آراء أهل المدينة الفاضلة، مرجع سابق، ص 99 وما بعدها.

$$
23 \text { المرجع السابق، ص49. }
$$

24 الفـارابي، أبو نصر محمد بـن محمد: رسالة في العقل للفـارابي، تحقيق: موريس بويج، بيروت، المطبعة الكاثوليكية، 1938، ص12.

$$
25 \text { المرجع السابق، ص25 وما بعدها. }
$$

26 ابن سينا: أبو علي: الشفاء -- الطبيعيات - النفس - تحقيق الأب جورج قنواتي - سعيد زايد - القاهرة - 1975، ص12. 27 ابن سينا، أبو علي: النجاة، مطبعة السعادة، 1338 هـ، ص 158.

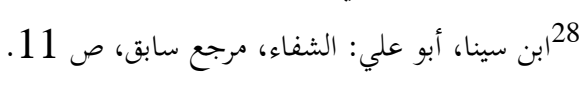

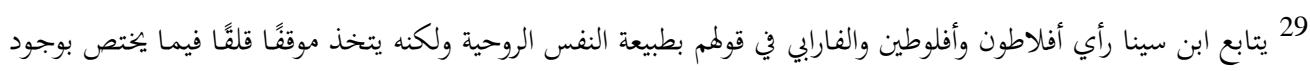

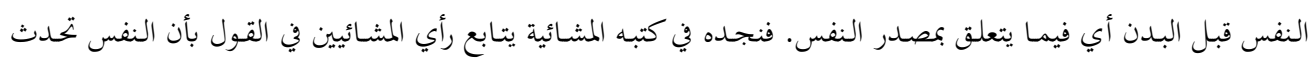

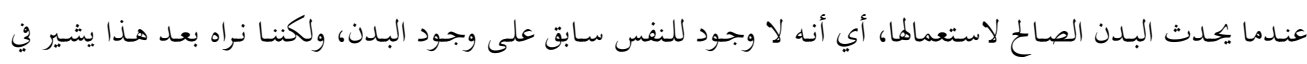

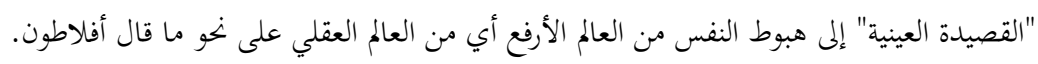

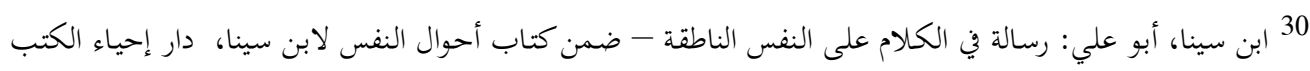

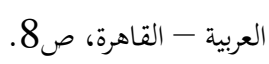

31 ابن سينا، أبو علي: رسالة في معرفة النفس الناطقة - نشرها الدكتور محمد ثابت الفندي ثم نشرها أحمد فؤاد الأهواني عام

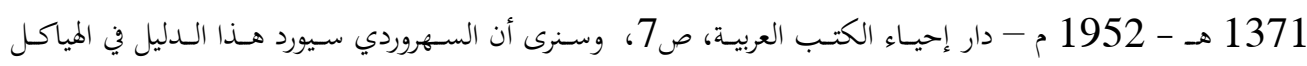

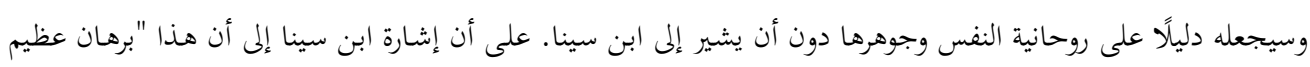

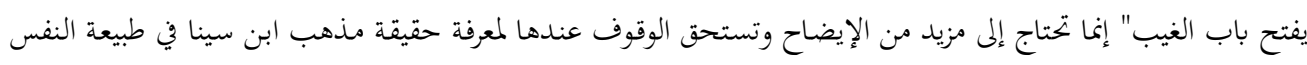
ومصدرها ومدى معارضته للموقف المشائي الذي عرضه في "الشفاء" و "النجاة". 32 وابن سينا يتابع موقف أفلاطون الحقيقي القائل بوحدة النفس وقد فهم بعض مؤرخي الفلسفة (الدكتور محمود قاسم - في النفس والعقل لفلاسفة الإغريق والإسلام ص 59 - 60 - 79) أن أفلاطون يقول بنفوس ثلاث هي بلفي النفس الشهوانية

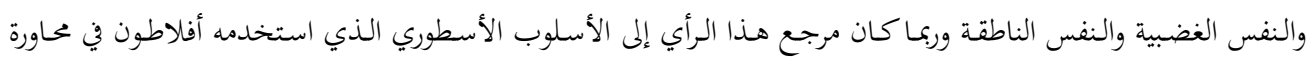

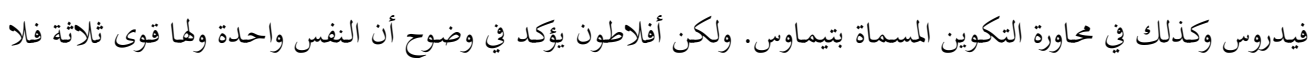

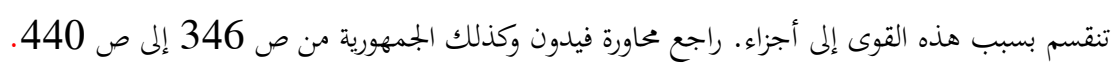


33 ابن سينا أبو علي - الإشارات والتنبيهات مع شرح نصر الدين الطوسي - تحقيق سليمان دنيا، دار المعارف، مصر - 1957م،

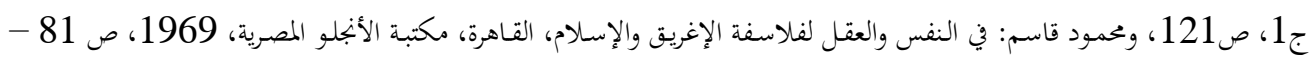

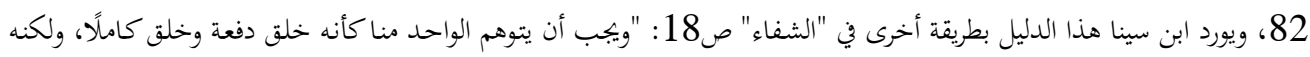

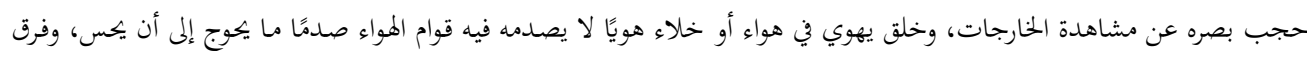

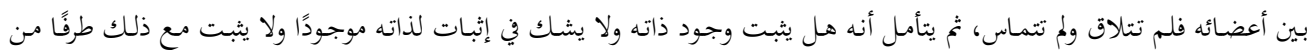

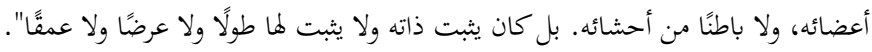

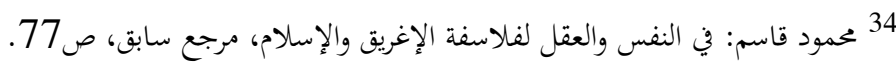

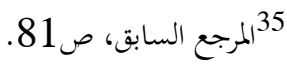
36 البارون كارادى فو: ابن سينا، ترجمة عادل زعيتر، دار إحياء الكتب العربية سنه 1959م القاهرة، ص226. 37 المرجع السابق، ص228.

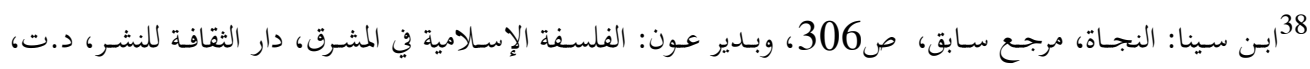
ص342، 342. 39 محمد علي أبو ريان: تاريخ الفكر الفلسفي، مرجع سابق، ص 3400.

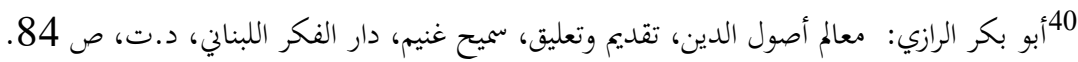

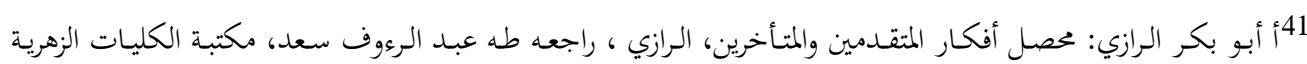
الخصل، ص228. 42 أبراهيم مدكور: في الفلسفة الإسلامية منهج وتطبيقه، مرجع سابق، ص 183.

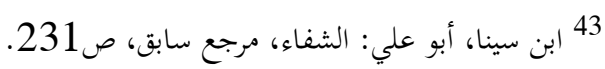
44 45 فيما يختص بالنفس وقواها عند ابن سينا، انظر: ابن سينا، أبو علي: الشفاء، مرجع سابق، ص 40 وما بعدها، وكذلك

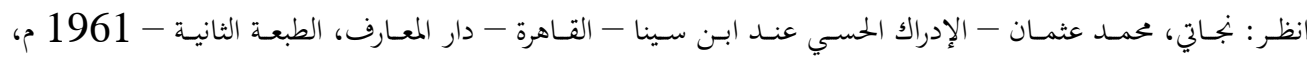

(46) انظر : ميلود حميدات: تحليل النفس وتشخيص أحواها ووصف أمراضها عند الغزالي، دار المنظومة.

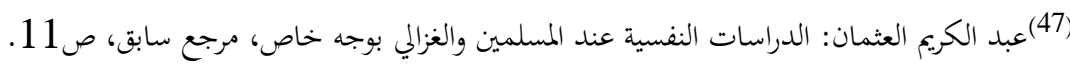

$$
\begin{aligned}
& \text { (48) سورة الفجر، آية } 27 \text { - } 28 \text { (49) } \\
& \text { (49) سورة القيامة، آية2. } \\
& \text { (50) سورة يوسف، آية } 53 .
\end{aligned}
$$




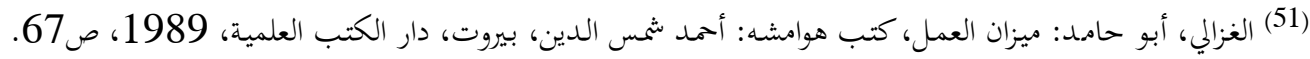

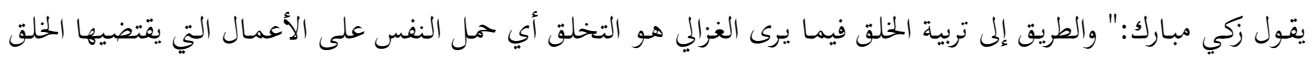

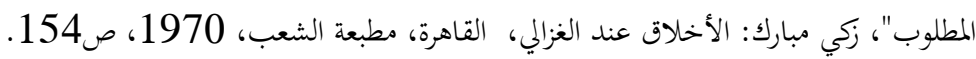

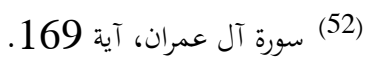

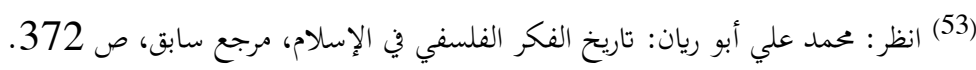

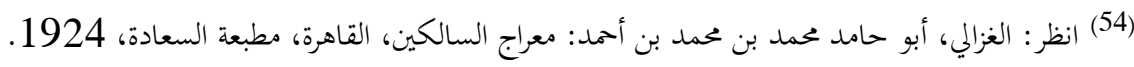

